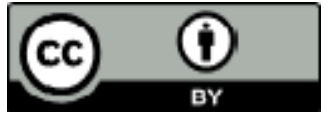

Lorna Rajle ${ }^{1}$

Elenmari Pletikos Olof ${ }^{2}$

Blaženka Martinović ${ }^{3}$

${ }^{1}$ Filozofski fakultet Osijek

${ }^{2}$ Filozofski fakultet Zagreb

${ }^{3}$ Filozofski fakultet Sveučilišta Jurja Dobrile u Puli
UDK 811.163.42'342.8(497.50sijek)

Izvorni znanstveni članak

Prihvaćen za tisak 28.05. 2020.

https://doi.org/10.29162/jez.2020.3

\title{
Zanaglasne dužine u osječkom govoru
}

Jedno je od nestabilnih mjesta hrvatske ortoepske norme naglasni sustav i u okviru njega izgovor/ostvaraj zanaglasnih dužina. Novija istraživanja hrvatskoga govora pokazuju da u mnogim hrvatskim urbanim govorima nestaje razlikovanje (ili ga i nema) dugih i kratkih zanaglasnih slogova te da je reduciranje dužina prisutno i u govorima s novoštokavskim četveronaglasnim sustavom (Pletikos Olof 2013). Ta se pojava često objašnjava posljedicom obilježenosti i niskog stupnja poželjnosti ostvarivanja zanaglasnih dužina među govornicima hrvatskog jezika (Škarić i Lazić 2002). Budući da standardna norma treba određivati ono što je stilski neutralno i neobilježeno, jezikoslovci u tom segmentu prešutno prihvaćaju odmak od propisa. U svjetlu proučavanja hrvatskih urbanih govora cilj je rada opisati ostvaraje zanaglasnih dužina u osječkom govoru (posebice u paradigmi imenica e-vrste, u nekim sufiksima te u prezentu glagola i određenim oblicima pridjeva) te ih usporediti s ostvarajem modelskoga govornika hrvatskoga standarda kada namjerno izgovara i ne izgovara zanaglasne dužine, čije vrijednosti trajanja uzimamo kao referentne vrijednosti za kategorije dugi i kratki. Dosadašnja su istraživanja pokazala da se u Osijeku, čiji govor pripada novoštokavskom četveronaglasnom sustavu, najčešće gube dužine koje nisu neposredno iza uzlaznih naglasaka te da slabe (ali se najčešće ne gube) i dužine iza uzlaznih naglasaka, osobito iza dugouzlaznog (Benić 2007), no ne postoji sustavniji opis zanaglasnih dužina u navedenim kategorijama riječi. Istraživanje se temelji na analizi govora Osječana koji su čitali rečenice zasićene riječima s očekivanim dužinama. Rezultati su pokazali da u osječkom govoru postoji tendencija reduciranja zanaglasnih dužina u pojedinim oblicima, ali rjeđe iza uzlaznih naglasaka.

Ključne riječi: zanaglasne dužine; urbani govori; osječki govor; uporaba; norma. 


\section{Uvod}

Zanaglasna dužina (zaudarna dužina) tradicionalno se naziva i nenaglašenom dužinom i u hrvatskom standardnom jeziku ostvaruje se samo iza naglašenog sloga. Ona u morfološkom smislu može imati razlikovnu ulogu, a pripada ili osnovi riječi, ili sufiksu, ili gramatičkom morfemu (Barić i dr. 1995: 69; Martinović 2014: 75). Zanaglasnu dužinu, prema propisanom standardu, imaju gramatički morfemi u pridjevsko-zamjeničkoj sklonidbi, gramatički morfemi u pojedinim padežima imeničke sklonidbe te gramatički morfemi u pojedinim kategorijama glagolskih paradigmi. Pritom se razlikuju tzv. sustavne dužine od gramatičkih dužina (vrsta gramatičkog morfema) (Jelaska 2004: 215-216; Martinović 2014: 75-80). Sustavne dužine javljaju se primjerice u sufiksima ili pred sonantom (u riječima poput: znanost, neutješnost, čuvar, mlinar, orač...), dok se gramatičke dužine javljaju u prezentskim gramatičkim morfemima, određenim oblicima pridjeva, genitivu množine, genitivu i instrumentalu jednine imenica e-vrste i sl. Sustavne dužine ne moraju ulaziti u fonološki sastav hrvatskoga jezika jer su nerazlikovne, no neki oblici gramatičkih dužina jesu razlikovni, pa ih treba smatrati fonološkom pojavom (Jelaska 2004: 215-216), odnosno ,dužina (je) činjenica strukture hrvatskoga jezika, pa onda i činjenica gramatike hrvatskoga jezika. I zato je treba pisati svugdje gdje to gramatika nalaže“ (Silić i Pranjković 2005: 20). Unatoč takvim standardološkim napucima neka istraživanja upućuju na činjenicu da se zanaglasne dužine u uporabnom hrvatskom reduciraju čak i u govoru izvornih novoštokavaca: „Drugo je njezin status (status dužine, nap. a.) u komunikaciji. U komunikaciji se naime ona i izgovara i ne izgovara" (Silić i Pranjković 2005: 20).

Štoviše, ostvaraj zanaglasnih dužina u hrvatskom se razgovornom jeziku uglavnom doživljava nepoželjnim te se često povezuje s govornikovim regionalnim podrijetlom i društvenim statusom, pri čemu se oni koji ih sustavno čuvaju nerijetko procjenjuju slabije obrazovanima i smještaju u kategoriju nižega društvenog statusa (Škarić i Lazić 2002; Martinović 2017).

Noviji jezikoslovni radovi koji se bave hrvatskom ortoepskom normom polaze od pretpostavke da ju je ,potrebno normirati na temelju odnosa uzusa i norme s uzorom u uporabnoj stvarnosti““ (Matešić 2009), tj. uzimati u obzir onaj uzusni odabir kojemu se daje prednost $u$ jezičnoj zajednici te predstavlja ,,argument stvarne jezične uporabe u zajednici“. K tome i u mnogim hrvatskim urbanim govorima nestaje razlikovanje (ili ga i nema) dugih i kratkih zanaglasnih slogova, a reduciranje dužina prisutno je i u govorima s novoštokavskim četveronaglasnim sustavom (Pletikos Olof 2013). 


\section{EZIKOSLOVLJE \\ 21.1 (2020): 53-80}

Kao prilog opisu hrvatskog uzusa, rad opisuje ostvaraje zanaglasnih dužina u osječkom govoru (posebice u paradigmi imenica e-vrste, u proširenim tvorbenim sufiksima te u prezentu glagola i određenim oblicima pridjeva), kao primjeru jednog od triju novoštokavskih dijalekata štokavskog narječja s četveronaglasnim sustavom za koji se pretpostavlja da u nekim oblicima još uvijek čuva zanaglasne dužine. Dosadašnja su istraživanja pokazala da se u Osijeku najčešće gube dužine koje nisu neposredno iza uzlaznih naglasaka te da slabe (ali se najčešće ne gube) i dužine iza uzlaznih naglasaka, osobito iza dugouzlaznog (Benić 2007), a ovaj rad daje sustavni opis zanaglasnih dužina u navedenim kategorijama riječi.

Tome se primarnom cilju - sustavnom opisu zanaglasnih dužina - pridodaje još jedan cilj, a to je usporedba dvaju metodoloških pristupa u istraživanju prozodijskih ostvaraja. Prvi među njima odnosi se na slušnu percepciju istraživača, što je vrlo zastupljena metoda u mnogim radovima u kojima se istražuju govori na terenu, dok se druga odnosi na akustičku analizu, uobičajenu u fonetičkim istraživanjima, koja na pitanje o egzaktnom postupku utvrđivanja ostvaraja odgovara uvođenjem usporedbe istraživanih ostvaraja s ostvarajima kod modelskoga govornika.

\section{Metodologija}

Ostvaraj zanaglasnih dužina u osječkom govoru istražen je na temelju slušne i akustičke analize govora devetero rođenih Osječana koji žive i rade u Osijeku, kojima je barem jedan roditelj proveo djetinjstvo i život u Osijeku te za koje se na temelju realizacije segmentnog i suprasegmentnog plana može tvrditi da su tipični osječki govornici. ${ }^{1}$ Sav govorni materijal korišten za istraživanje snimljen je aparatom $\mathrm{Zo}$ om H4n Pro 4-Channel Handy Recorder 4-kanalnim prijenosnim ručnim snimačem zvuka, a akustička analiza podataka učinjena je u programu Praat (Boersma i Weenik 2017).

Istraživanje je provedeno tako što je snimljen govor informanata koji čitaju unaprijed pripremljene rečenice $s$ riječima u kojima jezični priručnici propisuju zanaglasne dužine.

U jezičnom materijalu koji su govornici čitali bilo je zastupljeno ukupno 35 trosložnih riječi s prvim naglašenim slogom i propisanom dužinom na prvom ili drugom zanaglasnom slogu, ili pak s propisanim dužinama na oba zanaglasna sloga.

\footnotetext{
${ }^{1}$ Cjelokupni govorni materijal obuhvaća snimljeni govor 90 Osječana, od čega je za akustičku analizu izdvojeno devetero reprezentativnih govornika kod kojih je slušnom percepcijom procijenjeno da imaju najupečatljiviji ,osječki“ naglasak.
} 


\section{Lorna Rajle - Elenmari Pletikos Olof - Blaženka Martinović: \\ Zanaglasne dužine u osječkom govoru}

Riječi su stavljene u finalni rečenični položaj i rečenični kontekst koji nedvosmisleno ukazuje na traženo značenje riječi.

Primjeri riječi za analizu odabrani su prema kategorijama u kojima jezični priručnici propisuju zanaglasne dužine (etimološke ili fonetski uvjetovane dužine te dužine u osnovi ili korijenu riječi):

a) Imenice s dužinom na sufiksu

- imenice na -ost: spütānōst, mističnōst, skûčenōst, náklonōst

- imenice na -ik/-nik: prìvātnīk, rázrednīk, nástāvnīk, pùkōvnīk

- imenice na -ar: nädničār $r$ kòmičāa $r$, zâdrugār

b) Pridjevi s dužinom u osnovi i nastavku

- pridjevi na -an i -en: päsīvan, sìgūran, ràzdrāgān, nápōran, zámōran, zàdūǔen

- pridjevi na -ski i -čki: jädrānskī, hr̀vātskī, mòrnārskī, râdničk̄̄

c) Pridjevi s dužinom u pridjevsko-zamjeničkoj sklonidbi

- pridjevi u G ili A jd.: spâšenōg, smûšenōg

d) Imenice u genitivu i instrumentalu jednine imenica e-vrste

- öpekē, krìtikē, sádnicē

- püricōm, vëzicōm, pérnicōm, prírodōm

e) Prezent glagola

- glagoli u 1. 1. jd.: zàdūžīm, pòmognēm

- glagoli u 1. 1. mn.: pîtāmo, mäknēmo, živìmo

U ispitivanim riječima slušno i akustički analiziran je izgovor zanaglasnih vokala kod svih devetero govornika. Slušnom je analizom (koju su provele autorice rada) ponajprije utvrđen ostvaraj ili neostvaraj zanaglasne dužine u svakoj riječi u izgovoru svih govornika. Pritom je utvrđeno da se slušna procjena u jednom dijelu primjera podudara kod svih triju autorica (te su procjene smatrane sigurnima), a u drugom dijelu primjera kod samo dviju njih (te su procjene smatrane nesigurnima). Posebno su prikazane sigurne i posebno nesigurne procjene (Tablica 1), a posebno se donose i objedinjeni rezultati obiju procjena (Tablica 3). S obzirom na to da su postoci i sigurnih i nesigurnih procjena pokazali velik stupanj podudarnosti, u daljnjim analizama i usporedbama uzimani su u obzir rezultati objedinjenih sigurnih $i$ nesigurnih procjena.

Rezultati dobiveni slušnom procjenom uspoređeni su (Tablice 6, 7, 8 i 9) s akustičkim mjerenjima trajanja istih vokala modelskog govornika hrvatskog standarda kada izgovara i kada (s namjerom) ne izgovara zanaglasne dužine, čije su vrijednosti trajanja uzete kao referentne vrijednosti za kategorije dugi i kratki. Referentna je 


\section{EZIKOSLOVLJE \\ 21.1 (2020): 53-80}

govornica fonetičarka izvježbana izgovarati različite ostvaraje te joj je za potrebe našeg istraživanja kao smjernica za izgovor standarda s dužinama poslužio opis trajanja slogova koji donosi Škarić (1991: 322-323). Prije računanja prosječnih trajanja vokala i prije njihove usporedbe s referentnim vrijednostima izjednačena su tempa artikulacije Osječana i referentne govornice u svakoj izgovorenoj riječi ${ }^{2}$ te je tako dobiveno trajanje vokala koje bi govornik ostvarivao kada bi imao jednak tempo artikulacije kao referentna govornica. Tako izračunano trajanje vokala osječkih govornika uspoređeno je (Tablica 4 i 5) s trajanjem vokala modelske govornice hrvatskog standarda da bi se dobila realna razlika u trajanju vokala osječkih govornika i referentne govornice, tj. odnos trajanja naglašenog vokala između osječkog govora i neutralnog standarda. Tempo artikulacije (TA) za govornike i referentnu govornicu izračunan je prema formuli:

$$
\mathrm{TA}=\mathrm{n} / \mathrm{d}^{3}
$$

gdje je:

$\mathrm{n}$ - broj slogova u riječi

d - vrijeme artikulacije (trajanje izgovorene riječi),

a tempa artikulacije Osječana i referentne govornice izjednačena su prema formuli:

$$
\mathrm{d}_{\mathrm{i}}=\mathrm{TA}_{\mathrm{r}} \times \mathrm{d}_{\mathrm{r}} / \mathrm{TA}_{\mathrm{i}}
$$

gdje je:

$\mathrm{d}_{\mathrm{i}}$ - trajanje vokala koje bi ispitanik izgovarao kada bi imao jednak tempo artikulacije kao referentna govornica

$\mathrm{TA}$ - tempo artikulacije referentne govornice

$\mathrm{d}_{\mathrm{r}}-$ trajanje vokala referentne govornice

$\mathrm{TA}_{\mathrm{i}}$ - tempo artikulacije ispitanika

\footnotetext{
2 Prema Bakran (1996: 255), ,tempo artikulacije raste s povećanjem broja slogova izgovorne cjeline“. Prema tome proizlazi da se trajanje glasova u izgovoru smanjuje što je veći tempo artikulacije, no Bakran napominje da povećanje tempa artikulacije nije linearna funkcija povećanja broja slogova. Kako trajanje glasova, između ostaloga, ovisi uvelike o tempu artikulacije, odnosno o brzini izgovora, izmjerena trajanja glasova dviju osoba ne mogu se ni usporediti ako se ne izjednače tempa artikulacije.

${ }^{3}$ Bakran (1996: 254) formulu ispisuje kao TA $=\mathrm{n} / \mathrm{ta}$ (gdje je TA - tempo artikulacije, $\mathrm{n}$ - broj slogova, ta - vrijeme artikulacije, koje se dobiva iz formule: ta $=\operatorname{tg}-\operatorname{tp}$ (gdje je tg - ukupno vrijeme govorenja, tp - trajanje pauzi). Budući da je za potrebe ovoga istraživanja mjeren tempo artikulacije samo jedne riječi, pauza nije ni bilo, pa vrijeme artikulacije zapravo predstavlja izmjereno trajanje izgovora riječi. Zbog toga je simbol ta zamijenjen simbolom $d$.
} 


\section{Lorna Rajle - Elenmari Pletikos Olof - Blaženka Martinović: Zanaglasne dužine u osječkom govoru}

Razlog zbog kojega je trajanje vokala osječkih govornika uspoređeno s trajanjem vokala u dvama različitim izgovorima jedne referentne govornice jest taj što se čini da se u osječkom govoru, unatoč tendenciji gubljenja zanaglasnih dužina, u nekim oblicima riječi one ostvaruju, ali traju kraće od dužina koje izgovaraju profesionalni govornici kada teže govoriti standardom.

Budući da je jedan od ciljeva rada odrediti stvarnu razliku između modelske govornice i skupine osječkih govornika u trajanju vokala koji u hrvatskom standardnom jeziku nose zanaglasnu dužinu, to je uvjetovalo pristup utvrđivanju značajnosti rezultata mjerenja. Izračunata je aritmetička sredina akustički izmjerenih trajanja vokala kod skupine osječkih govornika i zatim je taj rezultat uspoređen s trajanjem vokala referentne govornice. Kako je poznato da promjene u trajanju kraćem od 10 ms nisu čujne (Lehiste 1970: 13), u provedenom istraživanju svaka razlika veća od 10 ms smatrala se značajnom.

\section{Rezultati i rasprava}

\subsection{Slušna percepcija}

Rezultati slušne percepcije gdje su autorice rada procjenjivale ostvaraj/neostvaraj zanaglasnih dužina kod devetoro osječkih ispitanika pokazuju da se sve tri procjeniteljice potpuno slažu u onome što čuju u 224 od ukupno 315 primjera, što iznosi $71 \%$. U 86 primjera (što iznosi 27\%) slažu se njih dvije, dok se u samo 5 primjera (2\%) sve tri razlikuju u mišljenjima. To znači da u $29 \%$ slučajeva nije sigurno izgovaraju li se pojedini primjeri riječi s ostvarenim zanaglasnim dužinama ili bez njih, ${ }^{4}$ pa je zbog toga ponajprije učinjena analiza sigurno procijenjenih pojavnica $(\mathrm{u}$ kojima su sve tri procjeniteljice jednako čule ostvaraj ili neostvaraj zanaglasne dužine), a zatim je to isto učinjeno i za nesigurno procijenjene pojavnice (u kojima su dvije procjeniteljice jednako čule ostvaraj ili neostvaraj zanaglasne dužine, v. Tablice 1, 2 i 3) kako bi se utvrdilo postoje li razlike u rezultatima. Primjeri u kojima se sve tri procjeniteljice razilaze u mišljenju oko ostvaraja zanaglasnih dužina nisu analizirani.

\footnotetext{
${ }^{4}$ Jedan od glavnih problema kod slušne percepcije možda je i taj što procjenitelji nesvjesno očekuju ostvaraj određenog naglaska i zanaglasne dužine pa ih tako i čuju, premda su možda drukčije izgovoreni. Zbog toga je metodu slušnog prepoznavanja potrebno upotpuniti akustičkim metodama da bi se eliminirao utjecaj subjektivnog doživljaja.
} 
Tablica 1. Ostvaraji/neostvaraji zanaglasnih dužina - slušna percepcija

\begin{tabular}{|c|c|c|c|c|c|c|c|c|c|c|c|c|c|c|c|c|c|c|}
\hline Govornik & \multicolumn{2}{|c|}{ G1 } & \multicolumn{2}{|c|}{ G2 } & \multicolumn{2}{|c|}{ G3 } & \multicolumn{2}{|c|}{ G4 } & \multicolumn{2}{|c|}{ G5 } & \multicolumn{2}{|c|}{ G6 } & \multicolumn{2}{|c|}{ G7 } & \multicolumn{2}{|c|}{ G8 } & \multicolumn{2}{|c|}{ G9 } \\
\hline & SP & NP & SP & NP & SP & NP & SP & NP & SP & NP & SP & NP & SP & NP & SP & NP & SP & NP \\
\hline sputānōst & $\mathbf{0}$ & & & 1 & 0 & & & 1 & 0 & & $\mathbf{0}$ & & $\mathbf{0}$ & & $\mathbf{0}$ & & 0 & \\
\hline mističnōst & 0 & & 0 & & 0 & & 0 & & $\mathbf{0}$ & & & 2 & & 0 & $\mathbf{0}$ & & & 2 \\
\hline skučenōst & 0 & & 0 & & & 0 & 0 & & 0 & & $\mathbf{0}$ & & & 0 & 0 & & 0 & \\
\hline naklonōst & $\mathbf{0}$ & & $\mathbf{0}$ & & 0 & & $\mathbf{0}$ & & $\mathbf{0}$ & & $\mathbf{0}$ & & & 2 & & 0 & & $\mathrm{R}$ \\
\hline$\Sigma$ pojavn. & 4 & 0 & 3 & 1 & 3 & 1 & 3 & 1 & 4 & $\mathbf{0}$ & 3 & 1 & 1 & 3 & 3 & 1 & 2 & 1 \\
\hline privātnīk & 1 & & & 1 & 0 & & & 0 & & 0 & 1 & & & 1 & 0 & & $\mathbf{0}$ & \\
\hline razrednīk & 2 & & $\mathbf{0}$ & & 0 & & $\mathbf{0}$ & & $\mathbf{0}$ & & $\mathbf{0}$ & & $\mathbf{0}$ & & 0 & & 0 & \\
\hline nastāvnīk & & 2 & & $\mathrm{R}$ & 0 & & & 1 & 0 & & & 0 & $\mathbf{0}$ & & & 1 & $\mathbf{0}$ & \\
\hline pukōvnīk & & 2 & 1 & & $\mathbf{0}$ & & 1 & & 1 & & 1 & & 1 & & 1 & & 1 & \\
\hline$\Sigma$ pojavn. & 2 & 2 & 2 & 1 & 4 & 0 & 2 & 2 & 3 & 1 & 3 & 1 & 3 & 1 & 3 & 1 & 4 & 0 \\
\hline nadničār & $\mathbf{0}$ & & $\mathbf{0}$ & & $\mathbf{0}$ & & $\mathbf{0}$ & & $\mathbf{0}$ & & $\mathbf{0}$ & & $\mathbf{0}$ & & $\mathbf{0}$ & & $\mathbf{0}$ & \\
\hline komičār & 2 & & $\mathbf{0}$ & & $\mathbf{0}$ & & $\mathbf{0}$ & & & 0 & 0 & & 0 & & 0 & & $\mathbf{0}$ & \\
\hline zâdrugār & & 2 & & 2 & 0 & & $\mathbf{0}$ & & & 0 & & & 2 & & & & & \\
\hline zadrùgār & & & & & & & & & & & 2 & & & & 2 & & 2 & \\
\hline$\Sigma$ pojavn. & 2 & 1 & 2 & 1 & 3 & 0 & 3 & 0 & 1 & 2 & 3 & 0 & 3 & 0 & 3 & 0 & 3 & 0 \\
\hline pasīvan & $\mathbf{0}$ & & & 2 & & 0 & $\mathbf{0}$ & & 0 & & 1 & & & 1 & 0 & & 0 & \\
\hline sigūran & $\mathbf{0}$ & & & 0 & $\mathbf{0}$ & & $\mathbf{0}$ & & $\mathbf{0}$ & & $\mathbf{0}$ & & $\mathbf{0}$ & & & 0 & & 1 \\
\hline zadūžen & & 1 & & $\mathrm{R}$ & & 0 & 1 & & & 1 & & 0 & & 1 & & 1 & & 1 \\
\hline razdrāgān & & 1 & & 1 & $\mathbf{0}$ & & $\mathbf{0}$ & & $\mathbf{0}$ & & 1 & & & 1 & 1 & & & 1 \\
\hline napōran & $\mathbf{0}$ & & $\mathbf{0}$ & & $\mathbf{0}$ & & $\mathbf{0}$ & & O & & $\mathbf{0}$ & & & 0 & $\mathbf{0}$ & & $\mathbf{0}$ & \\
\hline zamōran & 0 & & $\mathbf{0}$ & & 0 & & $\mathbf{0}$ & & 0 & & $\mathbf{0}$ & & 0 & & 0 & & $\mathbf{0}$ & \\
\hline$\sum$ pojavn. & 4 & 2 & 2 & 3 & 4 & 2 & 6 & 0 & 5 & 1 & 5 & 1 & 2 & 4 & 4 & 2 & 3 & 3 \\
\hline jadrānskī & $\mathbf{0}$ & & & 0 & 0 & & & 2 & 0 & & & 1 & & 1 & 0 & & $\mathbf{0}$ & \\
\hline hr̀vātskī & & 1 & 1 & & & 0 & & 0 & 1 & & 1 & & 1 & & $\mathbf{0}$ & & 1 & \\
\hline mornārskī & & 0 & & 1 & & 1 & $\mathbf{0}$ & & & 1 & 1 & & & 1 & & 0 & & 1 \\
\hline radničk̄̄ & $\mathbf{0}$ & & $\mathbf{0}$ & & 0 & & $\mathbf{0}$ & & $\mathbf{0}$ & & $\mathbf{0}$ & & & 0 & $\mathbf{0}$ & & $\mathbf{0}$ & \\
\hline$\Sigma$ pojavn. & 2 & 2 & 2 & 2 & 2 & 2 & 2 & 2 & 3 & 1 & 3 & 1 & 1 & 3 & 3 & 1 & 3 & 1 \\
\hline puricōm & & 0 & $\mathbf{0}$ & & 0 & & & 0 & 0 & & $\mathbf{0}$ & & $\mathbf{0}$ & & 0 & & $\mathbf{0}$ & \\
\hline vezicōm & 0 & & 0 & & 0 & & 0 & & 0 & & & 0 & 0 & & $\mathbf{0}$ & & 0 & \\
\hline pernicōm & $\mathbf{0}$ & & $\mathbf{0}$ & & $\mathbf{0}$ & & $\mathbf{0}$ & & 0 & & $\mathbf{0}$ & & $\mathbf{0}$ & & $\mathbf{0}$ & & $\mathbf{0}$ & \\
\hline prirodōm & $\mathbf{0}$ & & & 2 & 0 & & $\mathbf{0}$ & & $\mathbf{0}$ & & & 2 & $\mathbf{0}$ & & 0 & & $\mathbf{0}$ & \\
\hline$\Sigma$ pojavn. & 3 & 1 & 3 & 1 & 4 & 0 & 3 & 1 & 4 & 0 & 2 & 2 & 4 & 0 & 4 & 0 & 4 & 0 \\
\hline zadūžīm & & $\mathrm{R}$ & & 1 & 1 & & 1 & & & 1 & & $\mathrm{R}$ & & 2 & & 1 & & 1 \\
\hline pomognēm & & 0 & & 0 & $\mathbf{0}$ & & & 0 & & 2 & 2 & & $\mathbf{0}$ & & 0 & & & 0 \\
\hline$\Sigma$ pojavn. & $\mathbf{0}$ & 1 & 0 & 2 & 2 & 0 & 1 & 1 & $\mathbf{0}$ & 2 & 1 & 0 & 1 & 1 & 1 & 1 & $\mathbf{0}$ & 2 \\
\hline spašenōg & $\mathbf{0}$ & & & 2 & 0 & & $\mathbf{0}$ & & $\mathbf{0}$ & & $\mathbf{0}$ & & 0 & & 0 & & $\mathbf{0}$ & \\
\hline smušenōg & $\mathbf{0}$ & & & 2 & $\mathbf{0}$ & & $\mathbf{0}$ & & $\mathbf{0}$ & & $\mathbf{0}$ & & $\mathbf{0}$ & & 0 & & $\mathbf{0}$ & \\
\hline pitāmo & & 0 & $\mathbf{0}$ & & 0 & & & 0 & $\mathbf{0}$ & & $\mathbf{0}$ & & $\mathbf{0}$ & & $\mathbf{0}$ & & $\mathbf{0}$ & \\
\hline maknēmo & & 0 & $\mathbf{0}$ & & $\mathbf{0}$ & & 0 & & 0 & & $\mathbf{0}$ & & $\mathbf{0}$ & & & 1 & $\mathbf{0}$ & \\
\hline živīmo & & 2 & 1 & & 0 & & & 1 & 0 & & & 0 & 0 & & & 1 & & 1 \\
\hline$\Sigma$ pojavn. & 2 & 3 & 3 & 2 & 5 & 0 & 3 & 2 & 5 & 0 & 4 & 1 & 5 & 0 & 3 & 2 & 4 & 1 \\
\hline opekē & $\mathbf{0}$ & & $\mathbf{0}$ & & 0 & & $\mathbf{0}$ & & $\mathbf{0}$ & & $\mathbf{0}$ & & 0 & & 0 & & $\mathbf{0}$ & \\
\hline kritikē & 0 & & 0 & & $\mathbf{0}$ & & & 2 & 0 & & $\mathbf{0}$ & & $\mathbf{0}$ & & 0 & & & 2 \\
\hline sadnicē & & 0 & $\mathbf{0}$ & & 0 & & & 2 & $\mathbf{0}$ & & $\mathbf{0}$ & & & 2 & $\mathbf{0}$ & & $\mathbf{0}$ & \\
\hline$\Sigma$ pojavn. & 2 & 1 & 3 & 0 & 3 & 0 & 1 & 2 & 3 & 0 & 3 & 0 & 2 & 1 & 3 & 0 & 2 & 1 \\
\hline Ukupno & 21 & 13 & 20 & 13 & 30 & 5 & 24 & 11 & 28 & 7 & 27 & 7 & 22 & 13 & 27 & 8 & 25 & 9 \\
\hline
\end{tabular}

SP - sigurna procjena (sve tri procjeniteljice jednako čuju ostvaraj/neostvaraj zanaglasne dužine); NP - nesigurna procjena (dvije procjeniteljice jednako čuju ostvaraj/neostvaraj zanaglasne dužine); $\mathrm{R}$ - sve tri procjeniteljice različito čuju ostvaraj/neostvaraj zanaglasne dužine (pojavnice nisu ušle u statističku obradu); 0 - bez ostvarenih zanaglasnih dužina; 1 - ostvarena prva zanaglasna dužina; 2 - ostvarena druga zanaglasna dužina 


\section{Lorna Rajle - Elenmari Pletikos Olof - Blaženka Martinović: Zanaglasne dužine u osječkom govoru}

Kako su među riječima u kojima je ispitivan ostvaraj zanaglasnih dužina zastupljeni primjeri i s propisanom prvom i s propisanom drugom zanaglasnom dužinom, ali i s propisanim objema zanaglasnim dužinama, za svaku je riječ analiziran ostvaraj/neostvaraj pojedine dužine, odnosno kračine.

Kako je razvidno iz rezultata u Tablici 2, analizom sigurno procijenjenih pojavnica dobiveni su sljedeći podaci: od ukupno 92 pojavnice s očekivanim ostvarajem prve zanaglasne dužine koje su ušle u statističku obradu, u 22 slučaja (što iznosi $23,91 \%$ ) zaista se i čula zanaglasna dužina. Druga zanaglasna dužina ostvarena je u 7 slučaja od ukupno 176, što iznosi 3,98\%, a obje zanaglasne dužine nikad se ne ostvaruju u jednoj riječi, iako je očekivano da će biti ostvarene u 44 slučaja. U 195 slučaja od ukupno 224 (što iznosi 87,05\%) zanaglasne dužine nisu se ostvarile u izgovoru. Značajno je da je među sigurno procijenjenim pojavnicama najviše onih u kojima se ne ostvaruje nijedna zanaglasna dužina.

Nadalje, prema slušnoj percepciji, ostvaraj zanaglasne dužine ne ovisi o gramatičkoj kategoriji riječi te se ona češće čuje u iskonski dugim slogovima ili na mjestima duljenja pred skupom s prvim članom sonantom te neposredno iza naglašenog sloga, posebice iza kratkouzlaznog. Tako se u imenicama na -ost, -ik i -ar dužina na sufiksu ostvaruje u zanemarivom broju pojavnica (prema sigurnoj procjeni, samo u četiri slučaja od ukupno 97 (4,12\%), i to u riječima razrednik, komičar i zadrugar), a slično je i s dužinama u konjugaciji te pridjevsko-zamjeničkoj sklonidbi i sklonidbi imenica: za drugu zanaglasnu dužinu procijenjeno je da se sigurno ostvaruje samo u jednom od ukupno 4 primjera, i to u riječi pomognem (što iznosi 25\%). Rezultati također pokazuju da se dužina na sufiksu prema sigurnoj slušnoj procjeni najčešće ostvaruje u riječi zâdrugār (u 4 od 6 slučajeva, što iznosi 66,67\%). Međutim ovdje valja napomenuti da se ta riječ u Osijeku vrlo često naglašava i kao $z a$ drùgār (a upravo je tako izgovorilo troje od četvero ispitanika za koje je procijenjeno da su ostvarili zanaglasnu dužinu na zadnjem slogu), pa je time dužina na -ar zapravo prva zanaglasna, a ne druga (Tablica 1).

Tablica 2. Ukupan broj ostvarenih i neostvarenih zanaglasnih dužina prema sigurnoj procjeni

\begin{tabular}{|l|r|r|r|}
\hline & Broj pojavnica & \multicolumn{1}{|c|}{$\%$} & Ukupni broj mogućih pojavnica \\
\hline Ostvarena 1.zd & 22 & 23,91 & 92 \\
\hline Ostvarena 2. zd & 7 & 3,98 & 176 \\
\hline Ostvarene obje zd & 0 & 0,00 & 44 \\
\hline Nije ostvarena zd & 195 & 87,05 & 224 \\
\hline
\end{tabular}




\section{EZIKOSLOVLJE \\ 21.1 (2020): 53-80}

Veća sustavnost u ostvarajima zanaglasnih dužina u osječkom govoru primjećuje se pri analizi svake riječi zasebno. Naime, među sigurno procijenjenim pojavnicama prva zanaglasna dužina značajno se ostvarila (u više od $50 \%$ slučajeva) u primjerima: pùkōvnīk (u 7 od ukupno 8 slučajeva, što iznosi 87,50\%), hrvātskī (u 5 od ukupno 6 slučajeva, što iznosi 83,33\%), zàdūžǐm (u 2 od ukupno 2 slučaja, što iznosi 100\%) i zàdūžen (u 1 od 1 slučaja, što iznosi 100\%), a nešto rjeđe u riječima mòrnārskī (u 1 od 2 slučaja, što iznosi 50\%), prïvātnīk (u 2 od ukupno 5 primjera, što iznosi 40\%), ràzdrāgān (u 2 od 5 slučaja, što iznosi 40\%), živìmo (1 od 4 slučaja, što iznosi 25\%) i päsīvan (u 1 od 6 slučajeva, što iznosi 16,67\%). Primjetno je, dakle, da su to sve dužine neposredno iza naglašenog sloga (i to kratkouzlaznog) i(li) ispred skupa s prvim članom sonantom (pùkōvnīk, hrivātskī, zàdūǔżm, zàdūǔen, mòrnārskī, ràzdrāgān) ili je, rjeđe, riječ o iskonski dugim slogovima ili dužini u osnovi (prïvātnīk, päsīvan) (Tablica 1).

Važno je istaknuti da se u riječima u kojima se propisuju obje zanaglasne dužine (spütānōst, prïvātnīk, nástāvnīk, pùkōvnīk, ràzdrāgān, jädrānskī, hrìātskī, mòrnārskī, zàdūž̀̃m) prema sigurnoj procjeni ostvaruje samo prva (iako se često ni ona ne ostvaruje: od ukupno 44 pojavnice čuje se u 19 slučajeva, što iznosi $43,18 \%$ ), dok se druga zanaglasna dužina u tim primjerima prema sigurnoj procjeni uopće ne ostvaruje.

Ako se pak u statističku obradu uključe zajedno podaci i sigurnih i nesigurnih ostvaraja (dakle, pribroje li se navedenim rezultatima i primjeri u kojima su dvije procjeniteljice jednako čule ostvaraj ili neostvaraj zanaglasne dužine), rezultati su slični (Tablica 3): prva zanaglasna dužina ostvarena je u 58 od ukupno 143 očekivanih slučaja (što iznosi 40,56\%), druga zanaglasna dužina ostvarena je u 24 slučaja od ukupno očekivanih 230 (što iznosi 10,43\%), a obje zanaglasne dužine u istoj riječi nisu ostvarene ni jednom, premda je očekivano da će ih biti 78. U 228 slučaja od ukupno 310 (što iznosi 73,55\%) zanaglasne dužine nisu ostvarene u izgovoru.

Analizirano prema pojedinačnim slučajevima (što je vidljivo iz Tablice 3), prva zanaglasna dužina opet se značajno ostvaruje (u više od $50 \%$ slučajeva) u primjerima: zàdūǔı̆m (u 6 od 7 slučajeva, što iznosi 85,71\%), pùkōvnīk (u 7 od 9 slučajeva, što iznosi 77,78\%), zàdüžen (u 6 od ukupno 8 slučajeva, što iznosi 75\%), ràzdrāgān, hr̀vātskī i mòrnārskī (u svakoj riječi ostvaruje se u 6 od 9 slučajeva, što iznosi $66,67 \%$ ) te u naglasnoj inačici zadrùgār (u 3 od ukupno 3 slučajeva, što iznosi $100 \%)^{5}$

\footnotetext{
${ }^{5}$ Kao što je navedeno, u osječkom se govoru, uz zâdrugār, često javlja naglasna inačica zadrùgār, koju je tako izgovorilo troje od devet govornika. Zanimljivo je da je od četvero govornika kod kojih
} 


\section{Lorna Rajle - Elenmari Pletikos Olof - Blaženka Martinović: Zanaglasne dužine u osječkom govoru}

Tablica 3. Ukupan broj ostvarenih i neostvarenih zanaglasnih dužina tijekom slušne procjene (uključujući i sigurnu i nesigurnu procjenu)

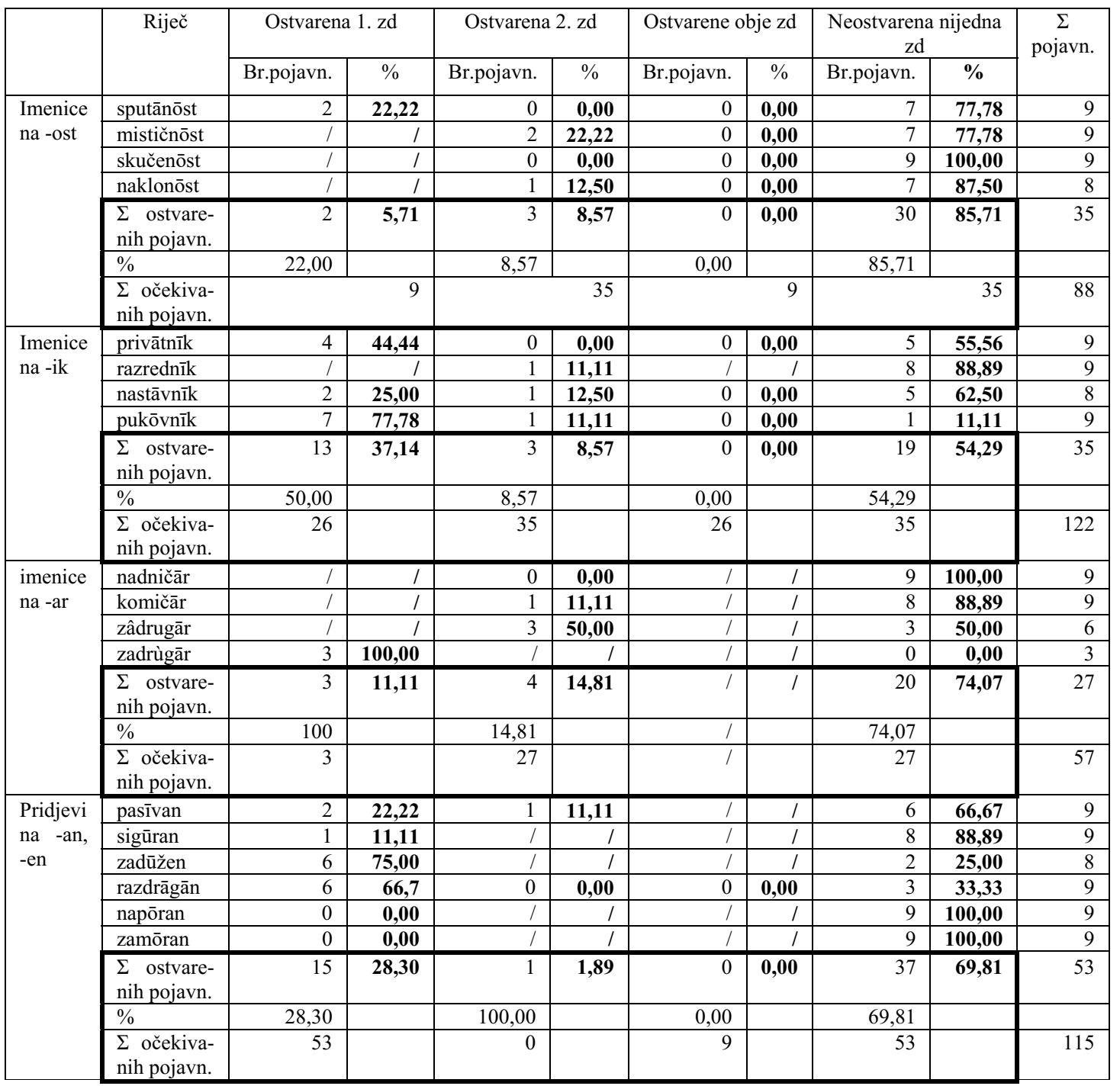

je sigurno procijenjen ostvaraj zanaglasne dužine na sufiksu -ar njih troje izgovorilo zadrùgār, što znači da je u tim slučajevima ostvarena prva (i krajnja) zanaglasna dužina. Slijedom toga, uključujući rezultate sigurne i nesigurne procjene, u riječi zadrugar zanaglasna dužina drugoga sloga od naglaska ostvarena je u tri od ukupno šest pojavnica (što iznosi 50\%), a prva od naglaska ostvarena je u tri od ukupni tri slučaja, što iznosi $100 \%$. 


\section{EZIKOSLOVLIE}

21.1 (2020): 53-80

\begin{tabular}{|c|c|c|c|c|c|c|c|c|c|c|}
\hline \multirow{7}{*}{$\begin{array}{l}\text { Pridjevi } \\
\text { na -ski, } \\
\text {-čki }\end{array}$} & jadrānskī & 2 & 22,22 & 1 & 11,11 & 0 & $\mathbf{0 , 0 0}$ & 6 & 66,67 & 9 \\
\hline & hrvātskī & 6 & 66,67 & 0 & 0,00 & 0 & 0,00 & 3 & 33,33 & 9 \\
\hline & mornārskī & 6 & 66,67 & 0 & 0,00 & 0 & 0,00 & 3 & 33,33 & 9 \\
\hline & radničkī & 1 & 1 & 0 & 0,00 & 1 & 1 & 9 & 100,00 & 9 \\
\hline & $\begin{array}{l}\Sigma \text { ostvare- } \\
\text { nih pojavn. }\end{array}$ & 14 & 38,89 & 1 & 2,78 & 0 & 0,00 & 21 & 58,33 & 36 \\
\hline & $\%$ & 51,85 & & 2,78 & & 0,00 & & 58,33 & & \\
\hline & $\begin{array}{l}\Sigma \text { očekiva- } \\
\text { nih pojavn. }\end{array}$ & 27 & & 36 & & 27 & $\mathbf{0}$ & 36 & & 126 \\
\hline \multirow{7}{*}{$\begin{array}{l}\text { Imenice } \\
\text { e-vrste } \\
\text { u I. jd. }\end{array}$} & puricōm & I & I & 0 & 0,00 & $\pi$ & I & 9 & 100,00 & 9 \\
\hline & vezicōm & 1 & 1 & 0 & 0,00 & 1 & I & 9 & 100,00 & 9 \\
\hline & pernicōm & 1 & 1 & 0 & 0,00 & 1 & 1 & 9 & 100,00 & 9 \\
\hline & prirodōm & 1 & 1 & 2 & 22,22 & 1 & 1 & 7 & 77,78 & 9 \\
\hline & $\begin{array}{l}\Sigma \text { ostvare- } \\
\text { nih pojavn. }\end{array}$ & I & 1 & 2 & 5,56 & 7 & I & 34 & 94,44 & 36 \\
\hline & $\%$ & 1 & 1 & 5,56 & & 1 & 1 & 94,44 & & \\
\hline & $\begin{array}{l}\Sigma \text { očekiva- } \\
\text { nih pojavn. }\end{array}$ & I & 1 & 36 & & & & 36 & & 72 \\
\hline \multirow{5}{*}{$\begin{array}{l}\text { Prezent } \\
\text { glagola } \\
\text { na -im, } \\
\text {-em }\end{array}$} & zadūžǐm & 6 & 85,7 & 1 & 14,3 & 0 & 0 & 0 & 0 & 7 \\
\hline & pomognēm & 1 & 1 & 2 & & 1 & 1 & 7 & & 9 \\
\hline & $\begin{array}{l}\Sigma \text { ostvare- } \\
\text { nih pojavn. }\end{array}$ & 6 & 37,50 & 3 & 18,75 & 0 & 0,00 & 7 & 43,75 & 16 \\
\hline & $\%$ & 85,71 & & 18,75 & & 0,00 & 0,00 & 43,75 & & \\
\hline & $\begin{array}{l}\Sigma \text { očekiva- } \\
\text { nih pojavn. }\end{array}$ & 7 & & 16 & & 7 & & 16 & & 46 \\
\hline \multirow{5}{*}{$\begin{array}{l}\text { Pridjevi } \\
\text { s nast. - } \\
\text { og }\end{array}$} & spašenōg & 1 & 1 & 1 & 11,11 & 7 & 1 & 8 & 88,89 & 9 \\
\hline & smušenōg & 1 & 1 & 1 & 11,11 & 1 & 1 & 8 & 88,89 & 9 \\
\hline & $\begin{array}{l}\Sigma \text { ostvare- } \\
\text { nih pojavn. }\end{array}$ & I & I & 2 & 11,11 & 7 & I & 16 & 88,89 & 18 \\
\hline & $\%$ & 1 & & 11,11 & & 1 & 1 & 88,89 & & \\
\hline & $\begin{array}{l}\Sigma \text { očekiva- } \\
\text { nih pojavn. }\end{array}$ & I & I & 18 & & I & I & 18 & & 36 \\
\hline \multirow{6}{*}{$\begin{array}{l}\text { Prezent } \\
\text { glagola, } \\
1.1 . \\
\mathrm{mn} .\end{array}$} & pitāmo & 0 & 0,00 & 1 & 1 & 7 & 1 & 9 & 100,00 & 9 \\
\hline & maknēmo & 1 & 11,11 & 1 & 1 & 1 & 1 & 8 & 88,89 & 9 \\
\hline & živīmo & 4 & 44,44 & 1 & 11,11 & 1 & 1 & 4 & 44,44 & 9 \\
\hline & $\begin{array}{l}\Sigma \text { ostvare- } \\
\text { nih pojavn. }\end{array}$ & 5 & 18,52 & 1 & 3,70 & T & I & 21 & 77,78 & 27 \\
\hline & $\%$ & 27,78 & & & & 1 & 1 & 77,78 & & \\
\hline & $\begin{array}{l}\Sigma \text { očekiva- } \\
\text { nih pojavn. }\end{array}$ & 18 & & I & & I & I & 27 & & 45 \\
\hline \multirow{6}{*}{$\begin{array}{l}\text { G. jd. } \\
\text { imenica } \\
\text { e-vrste }\end{array}$} & opekē & 1 & 1 & 0 & $\overline{0,00}$ & 7 & 1 & 9 & 100,00 & 9 \\
\hline & kritikē & 1 & 1 & 2 & 22,22 & 1 & 1 & 7 & 77,78 & 9 \\
\hline & sadnicē & 1 & 1 & 2 & 22,22 & 1 & 1 & 7 & 77,78 & 9 \\
\hline & $\begin{array}{l}\Sigma \text { ostvare- } \\
\text { nih pojavn. }\end{array}$ & I & I & 4 & 14,81 & T & I & 23 & 85,19 & 27 \\
\hline & $\%$ & & & 14,81 & & & & 85,19 & & \\
\hline & $\begin{array}{l}\Sigma \text { očekiva- } \\
\text { nih pojavn. }\end{array}$ & I & I & 27 & & I & I & 27 & & 54 \\
\hline \multirow[t]{2}{*}{ Ukupno } & $\begin{array}{l}\text { ostvarenih } \\
\text { pojavnica }\end{array}$ & $\overline{58}$ & $\overline{40,56}$ & 24 & $\overline{10,43}$ & $\overline{0}$ & $\overline{0,00}$ & 228 & 73,55 & \\
\hline & $\begin{array}{l}\text { očekivanih } \\
\text { pojavnica }\end{array}$ & 143 & & 230 & & 78 & & 310 & & \\
\hline
\end{tabular}




\section{Lorna Rajle - Elenmari Pletikos Olof - Blaženka Martinović: Zanaglasne dužine u osječkom govoru}

U primjerima prìvātnīk i živìmo prva se zanaglasna dužina ostvaruje u svakoj u 4 od ukupno 9 slučajeva (što iznosi 44,44\%), dok se u ostalim riječima ona čuje kao ostvarena u samo $25 \%$ slučajeva i manje, i to u: nástāvnīk (u 2 od 8 slučajeva, što iznosi 25\%), spütānōst, päsìvan i jädrānskī, (u svakoj se ostvaruje u 2 od 9 slučajeva, što iznosi 22,22\%) te sïgūran i mäknēmo (u svakoj se ostvaruje jednom od 9 slučajeva, što iznosi 11,11\%).

Ostvaraj krajnje zanaglasne dužine čuje se u riječima: mističnōst, prírodōm, pòmognēm, kritikē, sádnicēe (u svakoj se ostvaruje u 2 od ukupno 9 slučajeva, što iznosi 22,22\%), zàdūžìm (u 1 od 7 slučajeva, što iznosi 14,29\%), náklonōst i nástāvnīk (u svakoj u po jednom od 8 slučajeva, što iznosi 12,50\%) te rázrednīk, pùkōvnīk, kòmičār, jädrānskī, spâšenōg i smûšenōg (u svakoj u po jednom od 9 slučajeva, što iznosi 11,11\%) (Tablica 3).

Dakle, uključujući i sigurne i nesigurne ostvaraje u analizu, rezultati potvrđuju rezultate dobivene na temelju analize podataka s uključenim samo sigurnim ostvarajima: zanaglasna dužina najčešće se čuje neposredno iza kratkouzlaznog naglaska i(li) ispred skupa sa sonantom (pùkōvnīk, hr̀̀ātskī, zàdūžìm, zàdūǔen, mòrnārskī, ràzdrāgān), a zatim, nešto rjeđe, u iskonski dugim slogovima ili dužini u osnovi (prìvātnīk, živìmo), s tim da se u drugoj kategoriji dužine nesigurno i rjeđe čuju još u riječima: nástāvnīk, spütānōst, päsīvan, jädrānskī, sìgūran i mäknēmo. To samo donekle potvrđuje Benićevu (2007) tvrdnju da „slabe, ali se najčešće ne gube, i duljine iza uzlaznih naglasaka, osobito iza dugouzlaznoga“. Benićevi su rezultati dobiveni slušnom procjenom i nisu potvrđivani akustičkim analizama. Naime, rezultati ovog istraživanja pokazuju da se dužine ne gube uglavnom iza kratkouzlaznih naglasaka (u više od $50 \%$ slučajeva u sigurnoj procjeni i u čak više od $65 \%$ u nesigurnoj procjeni), dok se iza dugouzlaznih uglavnom gube (prema sigurnoj se procjeni ne ostvaruju, a prema nesigurnoj ostvaruju se u riječi nastavnik tek u $25 \%$ i u primjeru živimo u $44 \%$ slučajeva, a u riječima zamoran i naporan uopće se ne ostvaruju). Štoviše, dužine iza kratkouzlaznog naglaska (a tu se ubrajaju i riječi sa zanaglasnom dužinom ispred skupa s prvim članom sonantom) ostvaruju se u najvećem broju pojavnica od svih ispitivanih primjera, pa se može reći da je upravo to kategorija riječi u kojoj se u osječkom govoru, prema slušnoj percepciji, općenito najučestalije ostvaruje zanaglasna dužina. Nadalje, druga propisana zanaglasna dužina ne ostvaruje se ni u jednoj riječi u više od $22 \%$ slučaja, osim u riječi zâdrugāar, u kojoj se ona čuje u 3 od 6 slučajeva (što iznosi 50\%). Takav je rezultat dobio i Benić (2007), koji navodi: „duljine koje nisu neposredno iza uzlaznih naglasaka, najčešće se gube“. Međutim istraživanje je pokazalo da u osječkom govoru postoji još jedna kategorija riječi u kojoj se prema slušnoj procjeni donekle čuvaju zanaglasne dužine: one se ponekad ostvaruju i u iskonski dugim slogovima ili u riječima 
koje imaju dužinu u osnovi (doduše znatno rjeđe, prosječno od $11 \%$ do $44 \%$ ), a to su većinom primjeri s ostvarenom dužinom iza kratkosilaznog naglaska (prìvātnīk, živìmo, spütānōst, päsīvan, jädrānskī te sïgūran i mäknēmo).

Općenito, dakle, rezultati našega istraživanja dobiveni metodom slušne percepcije pokazuju da se zanaglasne dužine u osječkom govoru ostvaruju u 26,45\% slučajeva (prema nesigurnoj procjeni), što je gotovo jednak postotak onomu koji je dobila Pletikos (2013) ispitujući ostvaraj zanaglasne dužine u slavonskom izgovoru visokoobrazovanih govornika koji teže govoriti standardom (u njezinu su se istraživanju zanaglasne dužine čule u $24 \%$ riječi). No uzimajući u obzir samo rezultate sigurne procjene, zanaglasne se dužine u govoru Osječana ostvaruju čak znatno rjeđe - u samo $12,95 \%$ slučajeva.

\subsection{Akustička analiza}

Akustička analiza ukupnog broja pojavnica pokazala je da osječki govornici sve vokale u slogovima koji se propisuju kao zanaglasne dužine izgovaraju kraće od referentne govornice kada izgovara riječi s propisanim zanaglasnim dužinama: prvi zanaglasni vokal u izgovoru Osječana traje $103,66 \mathrm{~ms}(\mathrm{sd}=25,88)$, a drugi $94,89 \mathrm{~ms}(\mathrm{sd}=28,81)$, dok prvi zanaglasni vokal u izgovoru referentne govornice traje $146,53 \mathrm{~ms}(\mathrm{sd}=29,34)$, a drugi $138,56 \mathrm{~ms}(\mathrm{sd}=33,45)$. To znači da je prvi zanaglasni vokal kod Osječana kraći prosječno za $42,87 \mathrm{~ms}$, a drugi za $43,67 \mathrm{~ms}$ (Tablica 4).

Međutim u usporedbi s referentnom govornicom kada ne izgovara zanaglasne dužine, zanaglasni vokali propisani kao dugi kod osječkih govornika prosječno su duži: prvi kod osječkih govornika traje prosječno $73,49 \mathrm{~ms}(\mathrm{sd}=21,11)$, a drugi $70,04 \mathrm{~ms}$, dok prvi zanaglasni vokal u izgovoru referentne govornice traje $63 \mathrm{~ms}$ $(\mathrm{sd}=16,69)$, a drugi $62,81 \mathrm{~ms}(\mathrm{sd}=20,24)$. To znači da Osječani prvi zanaglasni slog izgovaraju duže od modelske govornice kad ne izgovara zanaglasne dužine prosječno za 10,49 ms, a drugi za samo 7,23 ms (Tablica 5), što je zanemarivo, imajući u vidu da se, prema Lehiste (1970: 13), razlika u trajanju koja je tek primjetna sluhu kreće između 10 i 40 ms. Rezultati su, dakle, na tragu Benićeva (2007) zaključka koji kaže da se u osječkom govoru zanaglasne dužine općenito „relativno krate", no on nema akustičkih analiza da bi se utvrdilo za koliko se krate. 


\section{Lorna Rajle - Elenmari Pletikos Olof - Blaženka Martinović: Zanaglasne dužine u osječkom govoru}

Tablica 4. Prosječna trajanja zanaglasnih vokala normaliziranog tempa artikulacije - usporedba osječkih govornika i modelske govornice hrvatskog standarda kada izgovara propisane zanaglasne dužine

\begin{tabular}{|c|c|c|c|c|c|c|c|c|c|c|c|c|}
\hline \multirow[t]{2}{*}{$\begin{array}{l}\text { Kategorija } \\
\text { riječi }\end{array}$} & \multirow{2}{*}{\multicolumn{2}{|c|}{ Riječ }} & \multicolumn{5}{|c|}{$\begin{array}{l}\text { Trajanje 1. zanaglasnog vokala } \\
\text { (u ms) }\end{array}$} & \multicolumn{5}{|c|}{$\begin{array}{l}\text { Trajanje 2. zanaglasnog vokala } \\
\text { (u ms) }\end{array}$} \\
\hline & & & $\begin{array}{l}\text { Trajanj } \\
\text { vokala } \\
\text { govorni }\end{array}$ & & $\begin{array}{l}\text { Trajanj } \\
\text { vokala } \\
\text { models } \\
\text { govorni }\end{array}$ & & $\begin{array}{l}\text { Razlika u } \\
\text { trajanju } \\
\text { vokala* }\end{array}$ & $\begin{array}{l}\text { Trajanje } \\
\text { vokala } \\
\text { govorni }\end{array}$ & & $\begin{array}{l}\text { Trajanje } \\
\text { vokala- } \\
\text { modelsk } \\
\text { govornic }\end{array}$ & & $\begin{array}{l}\text { Razlika u } \\
\text { trajanju } \\
\text { vokala* }\end{array}$ \\
\hline \multirow{6}{*}{$\begin{array}{l}\text { Imenice } \\
\text { na } \\
\text {-ost }\end{array}$} & \multicolumn{2}{|c|}{ spütānōst } & \multicolumn{2}{|c|}{88,43} & \multicolumn{2}{|c|}{148,00} & $-59,57$ & \multicolumn{2}{|c|}{87,75} & \multicolumn{2}{|c|}{101} & $-13,25$ \\
\hline & \multicolumn{2}{|c|}{ mìstičnōst } & \multicolumn{2}{|r|}{-} & \multicolumn{2}{|r|}{-} & - & \multicolumn{2}{|c|}{69,43} & \multicolumn{2}{|c|}{111} & $-41,57$ \\
\hline & \multicolumn{2}{|c|}{ skûčenōst } & \multicolumn{2}{|r|}{-} & \multicolumn{2}{|r|}{-} & - & \multicolumn{2}{|c|}{109,56} & & 66 & $-56,44$ \\
\hline & & nōst & & - & & - & - & & 2,88 & & 12 & $-29,12$ \\
\hline & $\overline{\mathbf{x}}$ & $\mathbf{n}$ & 88,43 & 9 & 148,00 & 1 & $-59,57$ & 87,40 & 36 & 122,50 & 4 & $-35,10$ \\
\hline & $\overline{\mathrm{sd}}$ & & 17 , & & 0 & & & 28, & & 29,42 & & \\
\hline Imenice & & & & 5,81 & &, 00 & $-43,19$ & & 2,01 & & 00 & $-9,99$ \\
\hline & & In̄ik & & - & & - & - & & 7,10 & & 00 & $-72,9$ \\
\hline$-i k$ & & nink & & 5,55 & & 00 & $-19,45$ & & 1,55 & & & $-56,45$ \\
\hline & & nīk & & 5,53 & & 00 & $-38,47$ & & 4,46 & & & $-21,54$ \\
\hline & $\overline{\mathbf{x}}$ & $\mathbf{n}$ & 118,97 & 27 & 152,67 & 3 & $-33,70$ & 101,32 & 36 & 141,50 & 4 & $-40,18$ \\
\hline & $\mathrm{sd}$ & & 22, & & 25,1 & & & 24 & & 37,57 & & \\
\hline & & & & - & & - & - & & 7,36 & & & $-51,64$ \\
\hline Imenice na & & & & - & & - & - & & 6,63 & & & $-32,37$ \\
\hline & & & & - & & - & - & & 9,84 & & & $-51,16$ \\
\hline & $\overline{\mathbf{x}}$ & $\mathrm{n}$ & & - & & - & - & 127,94 & 27 & 173,00 & 3 & $-45,06$ \\
\hline & $\mathrm{sd}$ & & & & & & & & 7,56 & & 23 & \\
\hline Pridjevi na & & & & 9,76 & &, 00 & $-66,24$ & & - & & - & - \\
\hline -an i & & & & 1,85 & &, 00 & $-79,15$ & & - & & - & - \\
\hline -en & & & & 6,00 & & 00 & $-32,00$ & & - & & - & - \\
\hline & & igān & & 8,14 & &, 00 & $-28,86$ & & 5,47 & & & $-32,53$ \\
\hline & & & & 9,79 & & 00 & $-75,21$ & & - & & - & - \\
\hline & & & & 0,00 & & 00 & $-52,00$ & & - & & - & - \\
\hline & $\overline{\mathbf{x}}$ & $\mathbf{n}$ & 104,26 & 54 & 159,83 & 6 & $-55,57$ & 105,47 & 9 & 138,00 & 1 & $-32,53$ \\
\hline & $\mathrm{sd}$ & & 24, & & 11,9 & & & 16 , & & 0 & & 0 \\
\hline Pridjevi na & & iskī & & 7,71 & &, 00 & 17,71 & & 4,62 & & & $-37,38$ \\
\hline -ski i & & & & 8,85 & &, 00 & $-22,15$ & & 6,95 & & & $-32,05$ \\
\hline -čki & & írskī & & 8,36 & & 00 & $-16,64$ & & 6,15 & & 00 & $-5,85$ \\
\hline & & & & - & & - & - & & 6,99 & 11 & & $-33,01$ \\
\hline & $\overline{\mathbf{x}}$ & $\mathbf{n}$ & 98,31 & 27 & 105,33 & 3 & $-7,02$ & 81,18 & 36 & 108,25 & 4 & $-27,07$ \\
\hline & $\mathrm{sd}$ & & 19 , & & 35,5 & & & 25 , & & 28,62 & & \\
\hline Imenice & & & & - & & - & - & & 7,74 & & & $-47,26$ \\
\hline e-vrste u I. & & & & - & & - & - & & 8,91 & & & $-84,09$ \\
\hline & & $\overline{o ̄ m}$ & & - & & - & - & & 5,70 & & & $-56,3$ \\
\hline & & ōm & & - & & - & - & & 4,29 & 13 & 00 & $-53,71$ \\
\hline & $\overline{\mathbf{x}}$ & $\mathbf{n}$ & & - & & - & - & 79,16 & 36 & 139,5 & 4 & $-60,34$ \\
\hline & $\mathrm{sd}$ & & & & & & & 18 & & 11,56 & & \\
\hline 1.1. jd. & & & & 5,84 & & 176 & $-40,16$ & & 5,90 & & & $-29,1$ \\
\hline prez. & & gnēm & & - & & - & - & & 8,91 & & & $-38,09$ \\
\hline glagola & $\overline{\mathbf{x}}$ & $\mathbf{n}$ & 135,84 & 9 & 176 & 1 & $-40,16$ & 92,41 & 18 & 126,00 & 2 & $-33,59$ \\
\hline $\begin{array}{l}\text { na } \\
\text {-im, } \\
\text {-em }\end{array}$ & $\overline{\mathrm{sd}}$ & & 12 , & & 0 & & & 20 , & & 15,56 & & \\
\hline
\end{tabular}




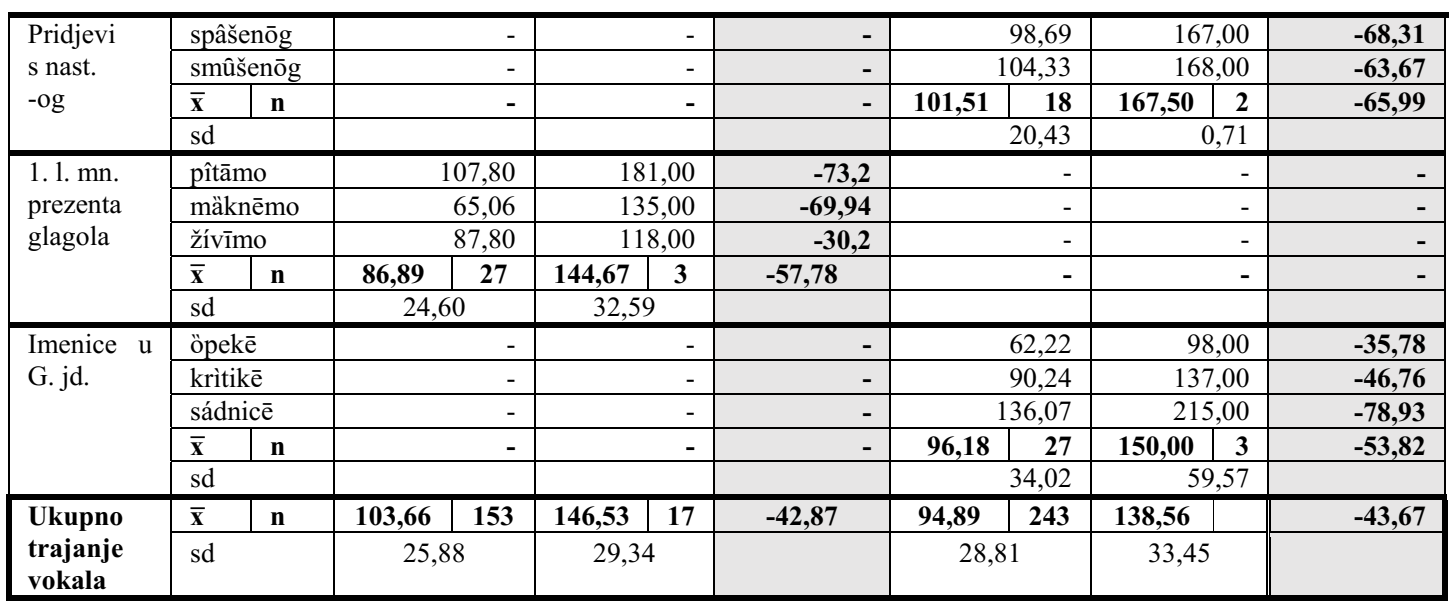

* Negativan broj kazuje da je trajanje vokala kod osječkog govornika kraće od vokala referentne govornice, a pozitivan broj znači da je vokal govornika duži od referentnog vokala.

Tablica 5. Prosječna trajanja zanaglasnih vokala normaliziranog tempa artikulacije (u ms) - usporedba osječkih govornika i modelske govornice kada s namjerom ne izgovara propisane zanaglasne dužine

\begin{tabular}{|c|c|c|c|c|c|c|c|}
\hline \multirow[t]{2}{*}{$\begin{array}{l}\text { Kategorija } \\
\text { riječi }\end{array}$} & \multirow[t]{2}{*}{ Riječ } & \multicolumn{3}{|c|}{$\begin{array}{l}\text { Trajanje 1. zanaglasnog vokala } \\
\text { (u ms) }\end{array}$} & \multicolumn{3}{|c|}{$\begin{array}{l}\text { Trajanje 2. zanaglasnog vokala } \\
\text { (u ms) }\end{array}$} \\
\hline & & $\begin{array}{l}\text { Trajanje } \\
\text { vokala - } \\
\text { govornici }\end{array}$ & $\begin{array}{l}\text { Trajanje } \\
\text { vokala - } \\
\text { modelska } \\
\text { govornica }\end{array}$ & $\begin{array}{l}\text { Razlika u } \\
\text { trajanju } \\
\text { vokala* }\end{array}$ & $\begin{array}{l}\text { Trajanje } \\
\text { vokala - } \\
\text { govornici }\end{array}$ & $\begin{array}{l}\text { Trajanje } \\
\text { vokala - } \\
\text { modelska } \\
\text { govornica }\end{array}$ & $\begin{array}{l}\text { Razlika u } \\
\text { trajanju } \\
\text { vokala* }\end{array}$ \\
\hline \multirow{6}{*}{$\begin{array}{l}\text { Imenice } \\
\text { na } \\
\text {-ost }\end{array}$} & spütānōst & 71,76 & 82,00 & $-10,24$ & 75,78 & 62 & 13,78 \\
\hline & mìstičnōst & - & - & - & 61,48 & 32 & 29,48 \\
\hline & skûčenōst & - & - & - & 82,79 & 67 & 15,79 \\
\hline & náklonōst & - & - & - & 70,37 & 72 & $-1,63$ \\
\hline & $\overline{\mathbf{x}}$ & 71,76 & 82,00 & $-10,24$ & 72,61 & 58,25 & 14,36 \\
\hline & $\mathrm{sd}$ & 16,60 & 0,00 & & 23,03 & 17,97 & \\
\hline \multirow{6}{*}{$\begin{array}{l}\text { Imenice } \\
\text { na } \\
\text {-ik }\end{array}$} & prìvātn̄̄k & 83,68 & 63,00 & 20,68 & 62,91 & 48,00 & 14,91 \\
\hline & rázrednīk & - & & & 71,84 & 65,00 & 6,84 \\
\hline & nástāvnīk & 81,74 & 45,00 & 36,74 & 73,87 & 88,00 & $-14,13$ \\
\hline & pùkōvnīk & 92,13 & 58,00 & 34,13 & 83,14 & 81,00 & 2,14 \\
\hline & $\overline{\mathbf{x}}$ & 85,85 & 55,33 & 30,52 & 72,94 & 70,50 & 2,44 \\
\hline & $\mathrm{sd}$ & 22,71 & 9,29 & & 20,03 & 17,82 & \\
\hline Imenice na & nädničār & - & - & & 87,55 & 93,00 & $-5,45$ \\
\hline & kòmičār & - & - & & 89,82 & 55,00 & 34,82 \\
\hline & zâdrugār & - & - & & 121,19 & 114,00 & 7,19 \\
\hline & $\overline{\mathbf{x}}$ & - & - & & 99,52 & 87,33 & 12,19 \\
\hline & $\mathrm{sd}$ & - & - & & 29,10 & 29,91 & \\
\hline Pridjevi na & päsīvan & 55,64 & 36,00 & 19,64 & - & - & \\
\hline -an i -en & sïgūran & 64,34 & 101,00 & $-36,66$ & - & - & \\
\hline & zàdūžen & 90,78 & 79,00 & 11,78 & - & & \\
\hline & ràzdrāgān & 80,71 & 49,00 & 31,71 & 63,48 & 85,00 & $-21,52$ \\
\hline & nápōran & 58,47 & 65,00 & $-6,53$ & - & - & \\
\hline
\end{tabular}




\section{Lorna Rajle - Elenmari Pletikos Olof - Blaženka Martinović: Zanaglasne dužine u osječkom govoru}

\begin{tabular}{|c|c|c|c|c|c|c|c|c|c|c|c|c|}
\hline & \multicolumn{2}{|c|}{ zámōran } & \multicolumn{2}{|r|}{70,38} & \multicolumn{2}{|c|}{69,00} & \multirow{2}{*}{$\begin{array}{c}1,38 \\
-3,55\end{array}$} & \multicolumn{2}{|c|}{-} & \multicolumn{2}{|r|}{-} & \multirow[b]{2}{*}{$-21,52$} \\
\hline & $\overline{\mathbf{x}}$ & $\mathbf{n}$ & 70,05 & 54 & 66,50 & 6 & & 63,48 & 9 & 85,00 & 1 & \\
\hline & \multicolumn{2}{|l|}{$\mathrm{sd}$} & \multicolumn{2}{|c|}{22,32} & \multicolumn{2}{|c|}{22,77} & & \multicolumn{2}{|c|}{16,74} & \multicolumn{2}{|c|}{0,00} & \\
\hline \multirow{6}{*}{$\begin{array}{l}\text { Pridjevi na } \\
\text {-ski i -čki }\end{array}$} & \multicolumn{2}{|c|}{ jädrānskī } & \multicolumn{2}{|c|}{67,92} & \multicolumn{2}{|c|}{45,00} & 22,92 & \multicolumn{2}{|c|}{65,98} & \multicolumn{2}{|c|}{43,00} & 22,98 \\
\hline & \multicolumn{2}{|c|}{ hr̀ātskī } & \multicolumn{2}{|r|}{72,44} & \multicolumn{2}{|c|}{64,00} & 8,44 & \multicolumn{2}{|c|}{43,42} & \multicolumn{2}{|c|}{26,00} & 17,42 \\
\hline & \multicolumn{2}{|c|}{ mòrnārskī } & \multicolumn{2}{|r|}{73,07} & & 00 & 17,07 & & 6,22 & & 00 & 12,22 \\
\hline & & & & - & & - & & & 6,94 & & 00 & 10,94 \\
\hline & $\overline{\mathbf{x}}$ & n & 71,14 & 27 & 55,00 & 3 & 16,14 & 58,14 & 36 & 42,25 & 4 & 15,89 \\
\hline & $\mathrm{sd}$ & & 12 & & 9,5 & & & 25, & & 12,3 & & \\
\hline Imenice & & & & - & & - & - & & 2,07 & & 00 & 3,07 \\
\hline e-vrste & & & & - & & - & - & & 4,74 & & 00 & 3,74 \\
\hline u I. jd. & & $\overline{o m}$ & & - & & - & - & & 9,87 & & 00 & 5,87 \\
\hline & prí & $\overline{\mathrm{o} m}$ & & - & & - & - & & 2,54 & & 00 & 13,54 \\
\hline & $\overline{\mathbf{x}}$ & n & & - & & - & - & 59,80 & 36 & 53,25 & 4 & 6,55 \\
\hline & $\mathrm{sd}$ & & & - & & - & & & 3,60 & & 35 & \\
\hline 1. 1. jd. prez. & & & & 98,74 & &, 00 & 12,74 & & 2,27 & & 00 & 11,27 \\
\hline glagola & & gnēm & & - & & - & - & & 9,78 & & 00 & 7,78 \\
\hline na -im, & $\overline{\mathbf{x}}$ & $\mathbf{n}$ & 98,74 & 9 & 86,00 & 1 & 12,74 & 61,03 & 18 & 51,50 & 2 & 9,53 \\
\hline -em & $\mathrm{sd}$ & & 13 , & & 0 & & & 15 , & & 0,7 & & \\
\hline Pridjevi & & $\overline{\mathrm{o} g}$ & & - & & - & - & & 9,69 & & 00 & $-2,31$ \\
\hline s nast. $-\mathrm{og}$ & & nōg & & - & & - & - & & 7,56 & & 00 & 11,56 \\
\hline & $\overline{\mathbf{x}}$ & $\mathbf{n}$ & & - & & - & - & 73,62 & 18 & 69,00 & 2 & 4,62 \\
\hline & $\mathrm{sd}$ & & & - & & - & & & 8,98 & & 24 & \\
\hline 1.1. mn. & & & & 65,16 & & 60 & 5,16 & & - & & - & - \\
\hline prezenta & & Èmo & & 56,39 & & 50 & 6,39 & & - & & - & - \\
\hline glagola & Žív & & & 65,95 & & 63 & 2,95 & & - & & - & - \\
\hline & $\overline{\mathbf{x}}$ & $\mathrm{n}$ & 62,50 & 27 & 57,67 & 3 & 4,83 & & - & & - & - \\
\hline & $\mathrm{sd}$ & & 15 , & & 6,8 & & & & - & & - & - \\
\hline Imenice $\mathrm{u}$ & öp & & & - & & - & - & & 7,29 & &, 00 & $-2,71$ \\
\hline G. jd. & krì & & & - & & - & - & & 6,57 & & 00 & 3,57 \\
\hline & & & & - & & - & - & & 3,26 & & 00 & 5,26 \\
\hline & $\overline{\mathbf{x}}$ & & & - & & - & - & 72,37 & 27 & 70,33 & 3 & 2,04 \\
\hline & $\mathrm{sd}$ & & & & & & & & 9,25 & & 83 & \\
\hline Ukupno & $\overline{\mathbf{x}}$ & $\mathrm{n}$ & 73,49 & 153 & 63,00 & 17 & 10,49 & 70,04 & 243 & 62,81 & 27 & 7,23 \\
\hline $\begin{array}{l}\text { trajanje } \\
\text { vokala }\end{array}$ & $\mathrm{sd}$ & & 21 , & & 16 , & & & 24 & & 20,2 & & \\
\hline
\end{tabular}

* Negativan broj kazuje da je trajanje vokala kod osječkog govornika kraće od vokala referentne govornice, a pozitivan broj znači da je vokal govornika duži od referentnog vokala

Uzimajući u obzir kategorije riječi, drugi zanaglasni vokal u imenicama na -ost (spütānōst, mističnōst, skûčenōst, náklonōst) kod osječkih govornika traje 87,40 ms $(\mathrm{sd}=28,53)$, što je za $35,10 \mathrm{~ms}$ kraće nego kod referentne govornice kada izgovara dužine (čiji vokal traje $122,50 \mathrm{~ms}$, sd $=29,42$ ). Isti je vokal za $14,36 \mathrm{~ms}$ duži od vokala govornice kada ne izgovara dužine. Naime, u izgovoru osječkih govornika on traje $72,61 \mathrm{~ms}(\mathrm{sd}=23,03)$, a kod referentne govornice kada s namjerom ne izgovara dužine traje $58,25 \mathrm{~ms}(\mathrm{sd}=17,97)$. Drugi zanaglasni vokal u imenicama na -ik kod osječkih govornika traje $101,32 \mathrm{~ms}(\mathrm{sd}=24,13)$ i prosječno je kraći od referentnog izgovorenog s dužinama za 40,18 ms (koji traje 141,50 ms, sd=37,57), a gotovo je jednak referentnom bez dužina (duži je tek za 2,44 ms). U imenicama na -ar drugi je zanaglasni vokal kraći od referentnog s dužinama čak za 45,06 ms, a od 
referentnog bez dužina duži za 12,19 ms. Vokal u drugom zanaglasnom slogu u pridjevima na -ski i -čki kraći je od referentnog s dužinama za $27,07 \mathrm{~ms}$, a od referentnog bez dužina duži za 15,89 ms. U nastavku za instrumental jednine imenica e-vrste drugi je zanaglasni vokal kod osječkih govornika prosječno kraći od referentnog s dužinama za $60,34 \mathrm{~ms}$, a duži od referentnog bez dužina za $6,55 \mathrm{~ms}$, dok je u nastavku za genitiv jednine od referentnog s dužinama kraći za $53,82 \mathrm{~ms}$, a od referentnog bez dužina duži za $2,04 \mathrm{~ms}$. U nastavcima za 1 . 1. jd. prezenta glagola na -im i -em kod osječkih je govornika vokal kraći od referentnog s dužinama za 33,59 ms i duži za 9,53 ms od referentnog bez dužina, a kod pridjeva u G ili A jd. na -og kraći je za 65,99 ms od referentnog s dužinama te duži od referentnog bez dužina za 4,62 ms (Tablice 4 i 5). Prema navedenom, vokale u propisano dugim drugim zanaglasnim slogovima u pojedinim kategorijama riječi osječki govornici izgovaraju redovito kraće od referentne govornice kada izgovara propisane zanaglasne dužine, i to u rasponu od $27,07 \mathrm{~ms}$ do $65,99 \mathrm{~ms}$, a u usporedbi s govornicom kada s namjerom ne izgovara zanaglasne dužine trajanja vokala Osječana uglavnom su nešto duža (u rasponu od 2,04 ms do 15,89 ms), ali ponegdje čak i kraća (u riječi razdragan drugi je zanaglasni vokal kraći za 21,52 ms od referentnog bez dužina!). Vidljivo je, dakle, da su Osječani po trajanju drugih zanaglasnih vokala bliži referentnoj govornici koja ne izgovara zanaglasne dužine, što je pokazala i slušna analiza: da se drugi zanaglasni slogovi čuju kao dugi u tek 3,98\% (prema sigurnoj procjeni), odnosno u 10,43\% slučajeva (prema nesigurnoj procjeni).

Kad je riječ o ostvarajima prvih zanaglasnih dužina gledanim po kategorijama riječi, prvi zanaglasni vokal u imenici spütānōst ${ }^{6}$ kod osječkih ispitanika traje kraće nego kod referentne govornice koja izgovara dužine za $59,57 \mathrm{~ms}$, ali je on za 10,24 ms kraći i od vokala referentne govornice kad ne izgovara dužine.

Prvi zanaglasni vokal u imenicama na -ik prosječno je kraći od referentnog s dužinama za 33,70 ms, a duži od referentnog bez dužina za 30,52 ms. Analizirane imenice na -ar nemaju propisane prve zanaglasne dužine, pa one nisu ni ulazile $u$ statističku obradu, kao ni primjeri genitiva jednine imenica e-vrste, no vokal u prvom zanaglasnom slogu u pridjevima na -ski i -čki kraći je od referentnog izgovorenog s dužinama za 7,02 ms, a od referentnog bez dužina duži za $16,14 \mathrm{~ms}$. Od primjera s propisanom prvom zanaglasnom dužinom u nastavcima za 1. 1. jd. prezenta glagola na -im i -em analiziran je samo primjer zàdūžìm i u njemu je kod osječkih govornika vokal kraći od referentnog s dužinama za 40,16 ms i duži za

\footnotetext{
${ }^{6}$ To je jedina ispitana riječ u toj kategoriji u kojoj je propisana prva zanaglasna dužina, pa nije poznato vrijedi li isto i za ostale imenice na -ost s propisanim prvim zanaglasnim dužinama. Za potvrdu rezultata potrebno je analizirati veći broj riječi.
} 


\section{Lorna Rajle - Elenmari Pletikos Olof - Blaženka Martinović: \\ Zanaglasne dužine u osječkom govoru}

12,74 ms od referentnog bez dužina, a u pridjeva na -an i -en kraći je za 55,57 ms od referentnog s dužinama te je kraći i od referentnog bez dužina za 3,55 ms. Vokal u slogu s propisanom zanaglasnom dužinom koji se javlja u osnovi 1. 1. množine prezenta glagola (pîtāmo, mäknēmo i živīmo) kod osječkih govornika prosječno je kraći za 57,78 ms od referentnog izgovorenog s dužinama, a za 4,83 ms duži od referentnog vokala izgovorenog bez dužine (Tablice 4 i 5).

U sljedećem koraku važno je usporediti slušnu percepciju ostvaraja ili neostvaraja zanaglasne dužine u pojedinoj riječi s pripadajućim izmjerenim vrijednostima dobivenima akustičkom analizom. Kako je prema slušnoj procjeni utvrđeno da ostvaraj zanaglasne dužine kod osječkih govornika ne ovisi o gramatičkoj kategoriji riječi, odnosno uglavnom se ne ostvaruju standardno propisane etimološke dužine (u sufiksima imenica, padežnim nastavcima za instrumental i genitiv jednine imenica ž. r. e-vrste, u nastavcima pridjeva te u 1. 1. jednine i 1.1. množine prezenta glagola), a češće se čuju neposredno iza naglašenog sloga, i to kratkouzlaznog, i(li) na mjestima duljenja pred skupom s prvim članom sonantom te $u$ iskonski dugim slogovima, rezultati akustičke analize prikazani su pojedinačno, neovisno o gramatičkoj kategoriji riječi te u odnosu na rezultate slušne percepcije.

Naime, vokali u zanaglasnim slogovima koji se percipiraju kao dužine u pravilu su kraći od vokala referentne govornice kada izgovara zanaglasne dužine (u 1. zanaglasnom slogu kraći su prosječno za $34,61 \mathrm{~ms}$, a u 2 . zanaglasnom slogu za $35,94 \mathrm{~ms}$ ) - osim 1. zanaglasnog vokala u riječi jadranski (koji je duži prosječno za $41,65 \mathrm{~ms}$ ) (Dodatak, Tablice 10 i 11) i 2. zanaglasnog vokala u riječima komičar (koji je kod govornika duži od referentnog za 26,10 ms), zadrugar (koji je kod govornika G6 duži od referentnog za 9,2 ms - usp. Dodatak, Tablica 7), jadranski (koji je duži od referentnog za 15,80 ms) i živimo (koji je kod govornika duži od referentnog za čak 73,40 ms) (Tablice 7 i 11) - a duži su od vokala referentne govornice kada s namjerom ne izgovara zanaglasne dužine - osim 1. zanaglasnog vokala u riječima siguran (koji je kod govornika kraći od referentnog za 30,56 ms), zadužen (koji je kod govornika G7 kraći za 7,02 ms, kod govornika G8 kraći je za $22,68 \mathrm{~ms}$, a kod govornika G9 za 7,22 ms), mornarski (koji je kod govornika G3 kraći za 0,83 ms) i živimo (koji je kod govornika G4 kraći za 8,4 ms) (Dodatak, Tablice 8 i 12) i 2. zanaglasnog vokala u riječi zadrugar (koji je kod govornika G7 kraći za 11,8 ms, a kod govornika G9 za 0,8 ms) (Dodatak, Tablice 9 i 13).

Premda akustička analiza ponegdje potvrđuje rezultate slušne percepcije gdje su zanaglasni slogovi s najdužim izmjerenim vokalom ujedno i procijenjeni dugima (primjerice 2. zanaglasna dužina u riječima pukovnik, komičar, nastavnik, jadranski, zadužim i živimo) (Dodatak, Tablica 7), zanimljivo je da nerijetko u izgovoru 
pojedinih riječi i govornika slušnom procjenom nije utvrđen ostvaraj zanaglasne dužine iako njihovi vokali traju podjednako ili čak duže od vokala govornika kod kojega se ostvaraj čuje (primjerice u riječi privatnik kod govornika G5 prvi zanaglasni vokal traje 149,3 ms i on se slušnom percepcijom nije doživio kao dug, dok kod govornika G6 isti vokal traje $116,1 \mathrm{~ms}$ i on se čak sigurnom procjenom čuo kao dužina - usp. Dodatak, Tablica 6; ili, u riječi náklonōst drugi zanaglasni slog, za koji je izmjereno kod ispitanika G3 da vokal traje 128,4 ms, slušnom percepcijom nije utvrđen kao zanaglasna dužina premda je taj isti slog percipiran kao dug kod govornika G7, kod kojega vokal traje tek 98,3 ms - usp. Dodatak, Tablica 7). ${ }^{7}$ Nepouzdano perceptivno razlikovanje vokala s obzirom na trajanje pokazala su i neka druga istraživanja (primjerice za slovenski, Tivadar 2004).

Navedeno može ukazivati na to da dužina vokala u slogu predstavlja samo jedan od čimbenika koji uvjetuju percipiranje zanaglasnih dužina te da u procjeni ostvaraja zanaglasne dužine ulogu ima trajanje svih glasova u slogu te odnos tona naglašenog i zanaglasnog vokala. To je problem koji bi valjalo ispitati.

\section{Zaključak}

Rezultati slušne percepcije gdje su autorice rada procjenjivale ostvaraj/neostvaraj zanaglasnih dužina kod 9 osječkih ispitanika pokazuju da se u $71 \%$ slučajeva sve tri procjeniteljice potpuno slažu u onome što čuju, u $27 \%$ slučajeva slažu se njih dvije, dok se u samo $2 \%$ slučajeva sve tri razlikuju u mišljenjima. S obzirom na odstupanja u procjeni, posebno su analizirani podaci sigurne procjene (u kojima su sve tri procjeniteljice jednako čule ostvaraj ili neostvaraj zanaglasne dužine), a zatim i ukupni podaci sigurne i nesigurne procjene (u kojima su samo dvije procjeniteljice jednako čule ostvaraj ili neostvaraj zanaglasne dužine), no i u jednom i u drugom slučaju dobiveni su slični rezultati: zanaglasne dužine u osječkom govoru, prema slušnoj procjeni, uglavnom se ne ostvaruju (u $87,05 \%$ slučajeva sigurne procjene te u $73,55 \%$ slučajeva ako su uključeni rezultati i sigurne i nesigurne procjene). Ako se ostvaruju, onda se to uglavnom odnosi na prve zanaglasne dužine, npr. u riječima pukovnik, hrvatski, zadužim, zadužen, mornarski, razdragan i nešto rjeđe u riječima privatnik, živimo, nastavnik, sputanost, pasivan, jadranski, siguran i maknemo (u 23,91\% slučajeva sigurne procjene te u $40,56 \%$ slučajeva i sigurne $\mathrm{i}$ nesigurne procjene), dok se druge zanaglasne dužine ostvaruju rijetko, npr. u riječima zadrugar, mističnost, prirodom, pomognem, kritike, sadnice, zadužim, naklonost, nastavnik te razrednik, pukovnik, komičar, jadranski, spašenog i smušenog (u

\footnotetext{
${ }^{7}$ Takvih je primjera više (usp. Tablice 6, 7, 8, 9).
} 


\section{Lorna Rajle - Elenmari Pletikos Olof - Blaženka Martinović: Zanaglasne dužine u osječkom govoru}

$3,98 \%$ sigurno procijenjenih slučajeva ili u $10,43 \%$ i sigurno i nesigurno procijenjenih slučajeva). U jednoj se riječi nikada ne ostvaruju obje zanaglasne dužine.

Uključujući, dakle, rezultate i sigurne i nesigurne procjene, dobiveni su podaci takvi da se može ustvrditi da se u osječkom govoru zanaglasna dužina uglavnom ne ostvaruje, a u slučaju kada se ostvaruje, to ne ovisi o gramatičkoj kategoriji riječi, pa se najčešće ne ostvaruju standardno propisane etimološke dužine (u sufiksima imenica, padežnim nastavcima za instrumental i genitiv jednine imenica ž. r. e-vrste, u nastavcima odnosnih pridjeva te u 1. 1. jednine i 1. 1. množine prezenta glagola), a češće se čuju dužine neposredno iza naglašenog sloga, i to ponajprije iza kratkouzlaznog naglaska i(li) na mjestima duljenja pred skupom s prvim članom sonantom.

Akustička analiza pokazala je da osječki govornici sve zanaglasne vokale koji se propisuju kao zanaglasne dužine izgovaraju znatno kraće od referentne govornice kada ona izgovara riječi s propisanim zanaglasnim dužinama: prvi je kraći prosječno za $42,87 \mathrm{~ms}$, a drugi za 43,67 ms. Međutim u usporedbi s referentnom govornicom kada ne izgovara zanaglasne dužine, zanaglasni vokali kod osječkih govornika prosječno su duži: prvi je duži za $10,49 \mathrm{~ms}$, a drugi za 7,23 ms. Analiza je također pokazala da Osječani druge zanaglasne slogove ponekad izgovaraju čak i kraće od referentne govornice kada s namjerom ne izgovara zanaglasne dužine. To ukazuje na reduciranje zanaglasnih dužina, što je potvrdilo rezultate slušne analize (drugi zanaglasni slogovi čuju se kao dugi vrlo rijetko).

Istraživanje je pokazalo da su vokali u slogovima u kojima se percipirala zanaglasna dužina kod Osječana najčešće kraći, i to za oko $35 \mathrm{~ms}$, od vokala referentne govornice kada izgovara zanaglasne dužine, ali i duži za oko 30 - 35 ms od vokala referentne govornice kada s namjerom ne izgovara zanaglasne dužine (iako postoje i primjeri koji to pravilo ne potvrđuju). Općeniti je zaključak, dakle, da je akustička analiza pokazala kako percipirane zanaglasne dužine (posebice kada je riječ o prvim zanaglasnim slogovima iza kratkouzlaznog naglaska i(li) ispred skupa s prvim članom sonantom, a nešto rjeđe i u iskonski dugim slogovima ili dužini u osnovi) u osječkome urbanom govoru traju kraće od onih kod referentne govornice kad izgovara dužinu te istodobno duže kad referentna govornica ne izgovara dužinu.

Iako akustička analiza ponegdje potvrđuje rezultate slušne percepcije gdje su zanaglasni slogovi s najdužim izmjerenim vokalom ujedno i procijenjeni dugima (primjerice u riječima pukovnik, komičar, nastavnik, jadranski, zadužim i živimo), zanimljivo je da se nerijetko u izgovoru pojedinih primjera slušnom procjenom ne utvrđuje ostvaraj zanaglasne dužine iako njihovi vokali traju podjednako ili čak duže od vokala govornika kod kojeg se ostvaraj čuje, i obratno: vokali u slogovima za 


\section{EZIKOSLOVLJE \\ 21.1 (2020): 53-80}

koje je procijenjen ostvaraj zanaglasne dužine ponekad su kraći od vokala koji se nalaze u slogovima za koje je procijenjeno da se zanaglasna dužina nije ostvarila, a sve, moguće je, zbog glasovne okoline i trajanja naglaska koji joj prethodi. Navedeno može ukazivati na to da dužina vokala u slogu predstavlja samo jedan od čimbenika koji uvjetuju percipiranje zanaglasnih dužina te je moguće da na procjenu njihova ostvaraja utječe i trajanje svih glasova u slogu te odnos tona naglašenog i zanaglasnog vokala.

\section{Literatura}

Bakran, Juraj. 1996. Zvučna slika hrvatskoga govora. Zagreb: Ibis grafika.

Barić, Eugenija; Lončarić, Mijo; Malić, Dragica; Pavešić, Slavko; Peti, Mirko; Zečević, Vesna; Znika, Marija. 1995. Hrvatska gramatika. Zagreb: Školska knjiga.

Benić, Mislav. 2007. Osnovni podaci o osječkoj akcentuaciji. Filologija 48. 1-28.

Jelaska, Zrinka. 2004. Fonološki opisi hrvatskoga jezika. Glasovi, slogovi, naglasci. Zagreb: Hrvatska sveučilišna naklada.

Lehiste, Ilse. 1970. Suprasegmentals. Cambridge, Massachusetts: MIT Press.

Martinović, Blaženka. 2014. Na putu do naglasne norme (oprimjereno imenicama). Zagreb: Hrvatska sveučilišna naklada i Sveučilište Jurja Dobrile u Puli.

Martinović, Blaženka. 2017. Kodifikacija hrvatske naglasne norme (ili kako naši priručnici govore). Rasprave: Časopis Instituta za hrvatski jezik i jezikoslovlje 43(1). 95-106.

Matešić, Mihaela. 2009. Hrvatska ortoepija između norme i uzusa. U Badurina, Lada i dr. (ur.), Jezični varijeteti i nacionalni identitet, Prilozi proučavanju standardnih jezika utemeljenih na štokavštini, 291-306. Zagreb: Disput.

Pletikos Olof, Elenmari. 2013. Akustičke različitosti naglasaka hrvatskoga štokavskoga sustava kod govornika iz Slavonije i Dalmacije. U Turk, Marija (ur.), A tko ide? / A hto tam idze? Hrvatski prilozi XV. Međunarodnom slavističkom kongresu, 351-376. Zagreb: Hrvatska sveučilišna naklada. Hrvatsko filološko društvo.

Silić, Josip; Pranjković, Ivo. 2005. Gramatika hrvatskoga jezika za gimnazije i visoka učilišta. Zagreb: Školska knjiga.

Škarić, Ivo. 1991. Fonetika hrvatskoga književnog jezika. U Babić, Stjepan; Brozović, Dalibor; Moguš, Milan; Pavešić, Slavko; Škarić, Ivo; Težak, Stjepko; Katičić, Radoslav (ur.), Povijesni pregled, glasovi i oblici hrvatskoga književnog jezika, 61-378. Zagreb: Hrvatska akademija znanosti i umjetnosti i Globus (Nakladni zavod).

Škarić, Ivo; Lazić, Nikolaj. 2002. Vrijednosni sudovi o hrvatskim naglascima. Govor 19(1). 5-34.

Tivadar, Hotimir. 2004. Fonetično-fonološke lastnosti samoglasnikov v sodobne knjižnem jeziku. Slavistička revija 52(1). 31-48. 


\section{Lorna Rajle - Elenmari Pletikos Olof - Blaženka Martinović: Zanaglasne dužine u osječkom govoru}

\section{DODATAK}

Tablica 6. Trajanje* prvih zanaglasnih dužina u ispitivanim riječima kod svakog govornika (u ms) - usporedba s modelskom govornicom hrvatskog standarda kada izgovara propisane zanaglasne dužine**

\begin{tabular}{|c|c|c|c|c|c|c|c|c|c|c|c|c|}
\hline & G1 & G2 & G3 & G4 & G5 & G6 & G7 & G8 & G9 & $\overline{\mathrm{x}}$ & $\mathrm{Sd}$ & $\begin{array}{l}\text { Ref. } \\
\text { gov. }\end{array}$ \\
\hline sputanost & 85,24 & 126,3 & 86,34 & 97,35 & 100,3 & 76,6 & 79,74 & 69,6 & 74,39 & 88,43 & 17,45 & 148 \\
\hline mističnost & 81,16 & 53,21 & 44,95 & 40,77 & 60,16 & 38,4 & 38,39 & 77,49 & 40,14 & 52,74 & 16,77 & 41 \\
\hline skučenost & 74,92 & 87,23 & 84,29 & 55,27 & 74,76 & 107,6 & 73,12 & 95,66 & 67,87 & 80,08 & 15,55 & 76 \\
\hline naklonost & 45,94 & 80,07 & 79,38 & 65,34 & 69,82 & 77,38 & 73,78 & 61,26 & 79,63 & 70,29 & 11,33 & 61 \\
\hline privatnik & $126,3^{66}$ & 124,2 & 125,4 & 95,03 & 149,3 & $116,1^{\prime \prime}$ & 116,7 & 85,67 & 103,6 & 115,81 & 18,98 & 159 \\
\hline nadničar & 94,31 & 77,21 & 81,28 & 85,41 & 105,5 & 84,82 & 81,43 & 69,07 & 62,1 & 82,35 & 12,79 & 72 \\
\hline pukovnik & 100,1 & $151^{\prime \prime}$ & 99,53 & $146,4^{46}$ & $141^{\prime \prime}$ & $158,6^{66}$ & $113,8^{66}$ & $146^{6}$ & $163,5^{66}$ & 135,53 & 24,57 & 174 \\
\hline komičar & 73,91 & 92,9 & 72,72 & 108,8 & 93,49 & 135,8 & 61,17 & 55,54 & 46,86 & 82,36 & 28,26 & 66 \\
\hline zadrugar & 68,31 & 72,62 & 64,27 & 59,29 & 57,53 & 86,58 & 58,44 & 105 & 110,2 & 75,80 & 20,19 & 44 \\
\hline nastavnik & 110,5 & 111,5 & 99,39 & 105,8 & 69,8 & 116,9 & 111,6 & 119 & 105,5 & 105,55 & 14,67 & 125 \\
\hline razrednik & 79,84 & 90,51 & 65,87 & 81,46 & 57,94 & 101 & 68,53 & 102,2 & 70,33 & 79,74 & 15,64 & 63 \\
\hline pasivan & 57,01 & 73,69 & 90,43 & 69,17 & 70,92 & $118,7 “ 6$ & 103,9 & 51,96 & 82,12 & 79,76 & 21,60 & 146 \\
\hline siguran & 87,45 & 96,24 & 108 & 65,67 & 94,24 & 125,1 & 86,58 & 65,56 & 97,79 & 91,85 & 18,88 & 171 \\
\hline zadužen & 122,6 & 147,1 & 136,9 & $132,7^{\prime 6}$ & 133,6 & 153,3 & 113 & 87,37 & 107,6 & 126,00 & 20,68 & 158 \\
\hline razdragan & 138,8 & 138,3 & 107,2 & 90,11 & 95,86 & $137,5^{\circ}$ & 131,1 & $105^{6}$ & 119,4 & 118,14 & 19,21 & 147 \\
\hline naporan & 75,69 & 117,7 & 109,9 & 114 & 112,9 & 87,78 & 114,8 & 64,33 & 101 & 99,79 & 19,39 & 175 \\
\hline zam & 115,7 & 116 & 110,2 & 102,5 & 72,41 & 144,5 & 128,5 & 91,49 & 108,8 & 110,00 & 20,66 & 162 \\
\hline jadranski & 89,71 & 93,63 & 75,48 & 71,84 & 75,35 & 102,8 & 120,5 & 76,21 & 83,95 & 87,71 & 15,97 & 70 \\
\hline hrvatski & 121,4 & $121,1^{\text {" }}$ & 115,4 & 115,1 & $121,8^{6}$ & $137,7^{\circ 6}$ & $120,7^{6}$ & 93,13 & $123,3^{6 / 6}$ & 118,85 & 11,65 & 141 \\
\hline mornarski & 92,8 & 77,03 & 72,9 & 80,75 & 91,35 & $93,2^{66}$ & 112,6 & 87,55 & 86,99 & 88,63 & 11,56 & 105 \\
\hline radnički & 71,63 & 64,36 & 70,06 & 53,25 & 70,26 & 63,63 & 62,64 & 43,71 & 55,89 & 61,71 & 9,23 & 55 \\
\hline maknemo & 53,99 & 71,3 & 89,43 & 32,1 & 65,72 & 92,24 & 62,38 & 59,8 & 58,62 & 65,06 & 18,23 & 135 \\
\hline puricom & 90,02 & 85,04 & 66,45 & 61,79 & 93,52 & 115,8 & 47,61 & 63,98 & 66,91 & 76,79 & 20,88 & 55 \\
\hline vezicom & 70,38 & 68,23 & 73,96 & 59,14 & 83,69 & 110,1 & 53,76 & 53,69 & 58,34 & 70,14 & 18,01 & 52 \\
\hline zadužim & 109,5 & 147,8 & $149,4^{6}$ & $136,7^{6}$ & 135 & 135,1 & 130,9 & 150,9 & 127,2 & 135,84 & 12,99 & 176 \\
\hline pomognem & 80,5 & 95,19 & 83,57 & 86,67 & 90,17 & 100,6 & 85,59 & 85,49 & 97,27 & 89,45 & 6,82 & 85 \\
\hline pitamo & 121,6 & 99,44 & 131,8 & 102 & 109,8 & 96,56 & 119,1 & 85,09 & 104,9 & 107,80 & 14,37 & 181 \\
\hline spašenog & 47,93 & 87,54 & 80 & 69,46 & 61,58 & 98,84 & 75,84 & 62,87 & 64,75 & 72,09 & 15,29 & 67 \\
\hline smušenog & 75,28 & 95,45 & 67,96 & 78,84 & 86,63 & 90 & 88,18 & 82,56 & 74,62 & 82,17 & 8,74 & 54 \\
\hline živimo & 88,34 & $116,9^{46}$ & 115,2 & 76,3 & 54,21 & 75,99 & 78,99 & 85,69 & 98,6 & 87,80 & 19,98 & 118 \\
\hline pernicom & 87,1 & 74,84 & 88,13 & 55,36 & 86,88 & 121,1 & 45,39 & 68,74 & 75,06 & 78,07 & 21,80 & 90 \\
\hline prirodom & 100,2 & 81,67 & 87,22 & 99,96 & 87,09 & 87,87 & 86,73 & 80,45 & 73,22 & 87,15 & 8,68 & 89 \\
\hline opeke & 67,65 & 70,54 & 56,8 & 54,17 & 50,81 & 79,02 & 59,46 & 73,36 & 53,69 & 62,83 & 10,04 & 49 \\
\hline kritike & 82,18 & 79,29 & 63,04 & 27,25 & 46 & 72,21 & 64,61 & 44,82 & 45,61 & 58,33 & 18,46 & 60 \\
\hline sadnice & 97,03 & 94,14 & 86,37 & 82,07 & 55,35 & 97,88 & 82,51 & 65,76 & 52,38 & 79,28 & 17,43 & 55 \\
\hline
\end{tabular}

*Trajanje vokala označava normaliziranu vrijednost prema tempu artikulacije modelske govornice hrvatskog standarda, a ne stvarno izmjereno trajanje vokala; ** Osjenčane su vrijednosti vokala u slogovima s percipiranom zanaglasnom dužinom;

"Sigurno procijenjene zanaglasne dužine 


\section{EZIKOSLOVLJE \\ 21.1 (2020): 53-80}

Tablica 7. Trajanje* drugih zanaglasnih dužina u ispitivanim riječima kod svakog govornika (u ms) - usporedba s modelskom govornicom hrvatskog standarda kada izgovara propisane zanaglasne dužine**

\begin{tabular}{|c|c|c|c|c|c|c|c|c|c|c|c|c|}
\hline 2. ZD & G1 & G2 & G3 & G4 & G5 & G6 & G7 & G8 & G9 & $\overline{\mathrm{x}}$ & $\mathrm{Sd}$ & $\begin{array}{l}\text { Ref. } \\
\text { gov. }\end{array}$ \\
\hline putanost & 107,8 & 138,4 & 112,3 & 70,01 & 85,62 & 95,32 & 87,02 & 29,36 & 63,87 & 87,75 & 31,49 & 101 \\
\hline mističnost & 59,01 & 64,58 & 85,81 & 46,96 & 78,26 & 74,37 & 91,43 & 54,61 & 69,81 & 69,43 & 14,63 & 111 \\
\hline skučenost & 120,2 & 127,7 & 159,8 & 81,06 & 103,7 & 86,87 & 110,1 & 80,29 & 116,3 & 109,56 & 25,57 & 166 \\
\hline naklonost & 117,4 & 68,81 & 128,4 & 48,3 & 79,53 & 81,53 & 98,3 & 49,65 & 74 & 82,88 & 27,59 & 112 \\
\hline privatnik & 106,3 & 75,6 & 86,62 & 92,49 & 59,04 & 102,4 & 69,55 & 64,07 & 83,66 & 82,19 & 16,53 & 92 \\
\hline nadničar & 94,47 & 122,3 & 105 & 104 & 149 & 133,7 & 116,6 & 116,3 & 114,8 & 117,36 & 16,42 & 169 \\
\hline pukovnik & 118,6 & 116 & 120 & 103,7 & 128,5 & 140 & 110 & 94,24 & 99,01 & 114,46 & 14,51 & 136 \\
\hline komičar & $175,1^{\prime \prime}$ & 123,9 & 97,78 & 115 & 103,5 & 117,2 & 114,8 & 121,5 & 81 & 116,63 & 25,74 & 149 \\
\hline zadrugar & 151,8 & 159,9 & 151,9 & 117,6 & 123 & 210,2 “ & $138,4^{46}$ & 156,76 & $139,1^{\prime \prime}$ & 149,84 & 26,95 & 201 \\
\hline nastavnik & 132,4 & 113,4 & 124,5 & 94,62 & 103,6 & 65,68 & 113,2 & 52,63 & 113,9 & 101,55 & 26,55 & 158 \\
\hline razrednik & $126,8^{\prime \prime}$ & 126,3 & 116,8 & 68,89 & 100,3 & 121,3 & 134,1 & 58,02 & 111,4 & 107,10 & 26,73 & 180 \\
\hline pasivan & 109,1 & 100,7 & 105,7 & 87,31 & 114,2 & 81,72 & 106,2 & 105 & 104,4 & 101,57 & 10,43 & 147 \\
\hline siguran & 105,6 & 124,3 & 101,1 & 73,08 & 81,73 & 82,81 & 94,4 & 75,82 & 94,89 & 92,63 & 16,31 & 109 \\
\hline zadužen & 133,1 & 101,1 & 110,6 & 97,96 & 91,6 & 111,1 & 88,74 & 101,2 & 84,55 & 102,22 & 14,71 & 115 \\
\hline razdragan & 115,4 & 119,8 & 123,9 & 106,3 & 118,2 & 111,8 & 83,76 & 92,87 & 77,3 & 105,47 & 16,84 & 138 \\
\hline naporan & 123,8 & 126,9 & 126 & 97,65 & 121,2 & 195,9 & 112,2 & 88,93 & 130,8 & 124,84 & 30,20 & 112 \\
\hline zamoran & 114,9 & 111,3 & 127,3 & 102,4 & 100,4 & 142 & 106,7 & 120,3 & 100,5 & 113,98 & 13,96 & 110 \\
\hline jadranski & 65,98 & 92,94 & 87,74 & 157,8 & 76,43 & 116,9 & 97,75 & 85,61 & 160,5 & 104,62 & 33,94 & 142 \\
\hline hrvatski & 91,9 & 60,6 & 75,63 & 73,32 & 61,33 & 86,03 & 86,77 & 71,88 & 85,05 & 76,95 & 11,29 & 109 \\
\hline mornarski & 57,58 & 65,42 & 59,44 & 61,11 & 72,07 & 65,8 & 74,32 & 78,49 & 61,13 & 66,15 & 7,28 & 72 \\
\hline radnički & 102,3 & 70,72 & 76,12 & 52,5 & 55,53 & 75,26 & 128,3 & 50,43 & 81,78 & 76,99 & 25,25 & 110 \\
\hline maknemo & 139,3 & 104,1 & 97,07 & 74,73 & 76,54 & 113,5 & 65,3 & 47,59 & 121,7 & 93,32 & 29,50 & 80 \\
\hline puricom & 89,4 & 87,26 & 86,74 & 58,33 & 69,81 & 91,06 & 73,02 & 53,87 & 90,16 & 77,74 & 14,45 & 125 \\
\hline vezicom & 56,47 & 64,84 & 103,3 & 54,42 & 78,67 & 107 & 60,88 & 30,79 & 63,84 & 68,91 & 24,12 & 153 \\
\hline zadužim & 97,71 & 86,14 & 93,57 & 70 & 87,29 & 84,86 & 111,3 & 51,57 & 90,71 & 85,90 & 16,96 & 115 \\
\hline pomognem & 77,03 & 82,2 & 107,1 & 73,59 & 122,2 & 125,1 “ & 123,7 & 70,52 & 108,8 & 98,91 & 22,95 & 137 \\
\hline pitamo & 166,2 & 126 & 124 & 118,3 & 135 & 82,09 & 105,4 & 102,6 & 100,1 & 117,73 & 24,29 & 126 \\
\hline spašenog & 131,7 & 126,3 & 110,8 & 86,57 & 111,3 & 102,1 & 78,47 & 51,67 & 89,27 & 98,69 & 25,06 & 167 \\
\hline smušenog & 118,3 & 108 & 124,9 & 101,9 & 121,9 & 100,6 & 93,46 & 77,84 & 92,16 & 104,33 & 15,52 & 168 \\
\hline živimo & 177,4 & 104,7 & 94,86 & 85,96 & 124,6 & 120,1 & 125,1 & 98,14 & 114,9 & 116,18 & 26,77 & 104 \\
\hline pernicom & 102,4 & 89,68 & 105,1 & 78,03 & 86,26 & 95,36 & 64,54 & 63,32 & 86,65 & 85,70 & 14,88 & 142 \\
\hline prirodom & 82,2 & 101 & 104,2 & 67 & 99,8 & 76,6 & 76,6 & 57,4 & 93,8 & 84,29 & 16,40 & 138 \\
\hline opeke & 81,31 & 67,07 & 69,61 & 45,35 & 60,62 & 56,04 & 56,91 & 67,72 & 55,37 & 62,22 & 10,45 & 98 \\
\hline kritike & 97,39 & 105,6 & 78,9 & 100,6 & 79,4 & 85,04 & 88,07 & 79,61 & 97,52 & 90,24 & 10,24 & 137 \\
\hline sadnice & 3 &, 9 & 5 &, 3 & ,9 & 127,5 & 145,7 & 69 & 1,7 & 136,07 & 20,49 & 5 \\
\hline
\end{tabular}

*Trajanje vokala označava normaliziranu vrijednost prema tempu artikulacije modelske govornice hrvatskog standarda, a ne stvarno izmjereno trajanje vokala; ** Osjenčane su vrijednosti vokala u slogovima s percipiranom zanaglasnom dužinom;

"Sigurno procijenjene zanaglasne dužine 


\section{Lorna Rajle - Elenmari Pletikos Olof - Blaženka Martinović: Zanaglasne dužine u osječkom govoru}

Tablica 8. Trajanje* prvih zanaglasnih dužina u ispitivanim riječima kod svakog govornika (u ms) - usporedba s modelskom govornicom hrvatskog standarda kada s namjerom ne izgovara zanaglasne dužine**

\begin{tabular}{|c|c|c|c|c|c|c|c|c|c|c|c|c|}
\hline 1. ZD & G1 & G2 & G3 & G4 & G5 & G6 & G7 & G8 & G9 & $\overline{\mathrm{x}}$ & $\mathrm{Sd}$ & $\begin{array}{l}\text { Ref. } \\
\text { gov. }\end{array}$ \\
\hline sputanost & 67,24 & 109 & 64,26 & 82,98 & 78,6 & 66,91 & 55,68 & 64,81 & 56,34 & 71,76 & 16,60 & 82 \\
\hline mističnost & 76,61 & 48,55 & 39,9 & 36,25 & 55,27 & 33,78 & 33,2 & 72,87 & 35,37 & 47,98 & 16,86 & 34 \\
\hline skučenost & 63,34 & 75,76 & 70,42 & 44,38 & 63,35 & 98,13 & 60,31 & 84,42 & 56,15 & 68,47 & 15,98 & 55 \\
\hline naklonost & 37,05 & 70,91 & 74,01 & 56,26 & 62,12 & 66,16 & 68,22 & 51,24 & 72,18 & 62,02 & 12,01 & 70 \\
\hline privatnik & $101,1^{\prime \prime}$ & 93,63 & 79,55 & 64,53 & 119,1 & $92,4^{66}$ & 78,54 & 59,74 & 64,52 & 83,68 & 19,64 & 63 \\
\hline nadničar & 79,96 & 63,69 & 69,59 & 71,21 & 92,44 & 70,54 & 69,48 & 54,83 & 49,27 & 69,00 & 12,73 & 67 \\
\hline pukovnik & 61,61 & 106,2 "“ & 45,28 & $104,8 “$ & $92,21^{\prime \prime}$ & 127,96 & 61,66 "6 & $112,2^{66}$ & $117,3^{6}$ & 92,13 & 29,00 & 58 \\
\hline komičar & 61,6 & 82,98 & 63,86 & 97,39 & 83,05 & 124,6 & 52,4 & 43,37 & 36,28 & 71,72 & 28,08 & 67 \\
\hline zadrugar & 63,86 & 68,82 & 61,99 & 54,44 & 53,52 & 82,58 & 55,4 & 100,3 & 106 & 71,87 & 19,89 & 47 \\
\hline nastavnik & 89,46 & 90,46 & 60,58 & 82,87 & 46,87 & 104,8 & 76,12 & 107,5 & 76,99 & 81,74 & 19,52 & 45 \\
\hline razrednik & 70,01 & 81,09 & 57,75 & 71,47 & 48 & 90,24 & 60,14 & 91,5 & 61,24 & 70,16 & 15,02 & 59 \\
\hline pasivan & 40,54 & 66,31 & 54,55 & 44,39 & 38,12 & $104,5^{6}$ & 62,92 & 40,3 & 49,19 & 55,64 & 20,89 & 36 \\
\hline siguran & 65,63 & 66,48 & 73,32 & 40,93 & 65,62 & 98,54 & 55,86 & 42,28 & 70,44 & 64,34 & 17,33 & 101 \\
\hline zadužen & 92,46 & 111,4 & 94,59 & $102,2^{\prime \prime}$ & 95,38 & 120,9 & 71,98 & 56,32 & 71,78 & 90,78 & 20,63 & 79 \\
\hline razdragan & 104 & 94,53 & 57,29 & 52,07 & 51,28 & $117,7^{6}$ & 88,96 & $81,38^{66}$ & 79,16 & 80,71 & 23,47 & 49 \\
\hline naporan & 44,93 & 75,32 & 54,27 & 65,99 & 67,8 & 58,55 & 71,33 & 34,29 & 53,73 & 58,47 & 13,23 & 65 \\
\hline zamoran & 84,36 & 73,24 & 61,23 & 67,94 & 36,51 & 103,4 & 85,51 & 54,61 & 66,59 & 70,38 & 19,44 & 69 \\
\hline jadranski & 69,78 & 73,31 & 54,76 & 53,51 & 54,85 & 83,53 & 99,88 & 57,65 & 64 & 67,92 & 15,69 & 45 \\
\hline hrvatski & 72,8 & 79,12 “ & 65,79 & 70,12 & $74,56^{66}$ & $92,86^{66}$ & $70,2^{\prime “}$ & 51,47 & $75,02^{\prime 6}$ & 72,44 & 11,00 & 64 \\
\hline mornarski & 77,91 & 61,65 & 55,17 & 67,88 & 73,84 & 79,36 "6 & 93,81 & 77,97 & 70,02 & 73,07 & 11,21 & 56 \\
\hline radnički & 68,28 & 60,76 & 65,93 & 50,24 & 66,54 & 60,28 & 60,3 & 41,21 & 52,65 & 58,47 & 8,86 & 45 \\
\hline maknemo & 58,33 & 62,03 & 68,41 & 31,12 & 52,12 & 83,59 & 46,06 & 61,92 & 43,91 & 56,39 & 15,29 & 50 \\
\hline puricom & 76,75 & 74,36 & 56,21 & 48,1 & 82,56 & 104 & 36,66 & 51,07 & 55,65 & 65,03 & 20,91 & 53 \\
\hline vezicom & 57,88 & 56,14 & 63,76 & 47,49 & 73 & 98,84 & 43,08 & 40,2 & 47,16 & 58,62 & 18,35 & 48 \\
\hline zadužim & 83,25 & 110,4 & $102,6^{66}$ & $105,4^{6 / 6}$ & 88,33 & 102,2 & 86,38 & 122,1 & 87,94 & 98,74 & 13,08 & 86 \\
\hline pomognem & 53,07 & 67,51 & 54,79 & 58,93 & 61,71 & 72,59 & 56,98 & 57,67 & 68,63 & 61,32 & 6,78 & 54 \\
\hline pitamo & 84,59 & 71,29 & 70,59 & 62,59 & 59,53 & 73,82 & 67,06 & 47,82 & 49,12 & 65,16 & 11,83 & 60 \\
\hline spašenog & 79,11 & 76,6 & 60,96 & 58,4 & 50,85 & 87,69 & 65,09 & 51,47 & 53,85 & 64,89 & 13,30 & 58 \\
\hline smušenog & 65,65 & 86,49 & 66,21 & 68,95 & 84,69 & 80,79 & 85,99 & 71,36 & 69,22 & 75,48 & 8,85 & 73 \\
\hline živimo & 67,57 & $98,14^{66}$ & 85,69 & 54,6 & 34,42 & 55,33 & 55,83 & 66,06 & 75,87 & 65,95 & 18,92 & 63 \\
\hline pernicom & 70,28 & 57,48 & 66,91 & 39,09 & 66,91 & 104,3 & 27,91 & 53,2 & 56,05 & 60,23 & 21,50 & 57 \\
\hline prirodom & 86,18 & 67,74 & 75,04 & 86,16 & 74,5 & 74,55 & 73,81 & 65 & 60,24 & 73,69 & 8,71 & 83 \\
\hline opeke & 56,71 & 59,18 & 46,14 & 42,51 & 40,54 & 68,38 & 49,27 & 60,54 & 42,61 & 51,76 & 9,78 & 44 \\
\hline kritike & 66,23 & 66,34 & 49,41 & 13,85 & 31,87 & 59,19 & 51,41 & 32,43 & 32,76 & 44,83 & 18,09 & 45 \\
\hline sadnice & 91,88 & 89,81 & 82,33 & 76,1 & 50,86 & 92,9 & 77,85 & 60,13 & 47,16 & 74,34 & 17,55 & 54 \\
\hline
\end{tabular}

*Trajanje vokala označava normaliziranu vrijednost prema tempu artikulacije modelske govornice hrvatskog standarda, a ne stvarno izmjereno trajanje vokala; ** Osjenčane su vrijednosti vokala u slogovima s percipiranom zanaglasnom dužinom;

"Sigurno procijenjene zanaglasne dužine 


\section{EZIKOSLOVLJE \\ 21.1 (2020): 53-80}

Tablica 9. Trajanje drugih zanaglasnih dužina* u ispitivanim riječima kod svakog govornika (u ms) - usporedba s modelskom govornicom hrvatskog standarda kada s namjerom ne izgovara zanaglasne dužine**

\begin{tabular}{|c|c|c|c|c|c|c|c|c|c|c|c|c|}
\hline 2. ZD & G1 & G2 & G3 & G4 & G5 & G6 & G7 & G8 & G9 & $\overline{\mathrm{x}}$ & $\mathrm{Sd}$ & $\begin{array}{l}\text { Ref. } \\
\text { gov. }\end{array}$ \\
\hline sputanost & 95,43 & 126,5 & 97,74 & 59,69 & 71,23 & 87,59 & 71,32 & 21,03 & 51,5 & 75,78 & 30,55 & 62 \\
\hline mističnost & 57,99 & 59,81 & 68,79 & 46,65 & 66,32 & 71,09 & 69,96 & 51,17 & 61,53 & 61,48 & 8,53 & 32 \\
\hline skučenost & 93,63 & 101,9 & 115,6 & 59,81 & 78,42 & 76,76 & 74,13 & 56,29 & 88,62 & 82,79 & 19,21 & 67 \\
\hline naklonost & 105,9 & 57,71 & 111,3 & 37,07 & 66,1 & 73,71 & 81,46 & 39,93 & 60,18 & 70,37 & 25,95 & 72 \\
\hline privatnik & 89,67 & 56,91 & 62,04 & 73,83 & 40,53 & 86,4 & 47,93 & 47,19 & 61,68 & 62,91 & 17,31 & 48 \\
\hline nadničar & 69,46 & 92,8 & 65,48 & 78,19 & 117 & 108,3 & 78,54 & 96,66 & 81,54 & 87,55 & 17,41 & 93 \\
\hline pukovnik & 88,86 & 84,29 & 85,14 & 72,96 & 95,46 & 112,8 & 75,89 & 66,04 & 66,79 & 83,14 & 14,94 & 81 \\
\hline komičar & $157,9 “$ & 92,91 & 60,73 & 92,86 & 75,5 & 93,84 & 77,18 & 103,6 & 53,87 & 89,82 & 30,34 & 55 \\
\hline zadrugar & 127,5 & 130,1 & 109,4 & 96,65 & 94,96 & $182,1^{\prime \prime}$ & $102,2^{\prime \prime}$ & $134,6^{\prime \prime}$ & $113,2^{\prime \prime}$ & 121,20 & 27,07 & 114 \\
\hline nastavnik & 106,9 & 87,85 & 85,51 & 67,6 & 76,6 & 46,87 & 76,7 & 34,18 & 82,67 & 73,87 & 21,95 & 88 \\
\hline razrednik & $95,21^{\prime \prime}$ & 88,71 & 60,66 & 39,52 & 70,11 & 102,6 & 81,78 & 38,84 & 69,18 & 71,84 & 22,75 & 65 \\
\hline pasivan & 84,87 & 81,3 & 71,15 & 64,69 & 81,25 & 58,73 & 68,94 & 83,33 & 71,38 & 73,96 & 9,16 & 73 \\
\hline siguran & 88,85 & 105,4 & 81,07 & 55,56 & 63,14 & 117,2 & 75,24 & 58,7 & 76,65 & 80,19 & 20,83 & 79 \\
\hline zadužen & 105,1 & 72,91 & 82,09 & 69,93 & 63,26 & 82,94 & 60,28 & 73,13 & 56,31 & 74,00 & 14,79 & 85 \\
\hline razdragan & 73,92 & 76,72 & 79,71 & 64,24 & 75,02 & 73,14 & 40,99 & 53,5 & 34,12 & 63,48 & 16,74 & 85 \\
\hline naporan & 100,2 & 102,6 & 101 & 73,69 & 96,79 & 172,4 & 87,89 & 65,33 & 106,3 & 100,70 & 30,28 & 84 \\
\hline zamoran & 93,08 & 91,56 & 108,6 & 81,22 & 79,47 & 121,9 & 86,95 & 100,1 & 80,63 & 93,72 & 14,31 & 99 \\
\hline jadranski & 25,79 & 48,16 & 38,46 & 136,2 & 29,64 & 84,82 & 49,62 & 61,2 & 120 & 65,98 & 39,53 & 43 \\
\hline hrvatski & 55,11 & 34,74 & 33,95 & 42,58 & 26,79 & 55,47 & 46,89 & 46,47 & 48,79 & 43,42 & 9,84 & 26 \\
\hline mornarski & 47,86 & 55,44 & 48,2 & 52,48 & 60,95 & 56,64 & 62,49 & 71,62 & 50,3 & 56,22 & 7,77 & 44 \\
\hline radnički & 91,57 & 58,41 & 60,36 & 44,03 & 42,38 & 64,57 & 124,1 & 45,26 & 71,78 & 66,94 & 26,50 & 56 \\
\hline maknemo & 133,6 & 96,24 & 87,29 & 68,15 & 67,94 & 105,7 & 56,27 & 41,5 & 112,9 & 85,51 & 29,56 & 60 \\
\hline puricom & 81,57 & 66,06 & 63,24 & 52,62 & 50,05 & 75,81 & 53,17 & 44,16 & 71,93 & 62,07 & 12,83 & 59 \\
\hline vezicom & 53,74 & 57,21 & 73,74 & 41,77 & 54,75 & 89,33 & 36,84 & 39,59 & 45,67 & 54,74 & 17,19 & 51 \\
\hline zadužim & 82,36 & 62,31 & 62,51 & 50,79 & 56,35 & 64,47 & 82 & 34,2 & 65,4 & 62,27 & 14,84 & 51 \\
\hline pomognem & 48,99 & 50,23 & 57,61 & 40,6 & 77,8 & 88,05 “ & 76,94 & 36,27 & 61,57 & 59,78 & 17,87 & 52 \\
\hline pitamo & 135,2 & 97,12 & 87,24 & 86,74 & 100,9 & 54,53 & 70,82 & 71,53 & 64,65 & 85,42 & 24,12 & 75 \\
\hline spašenog & 105,6 & 96,98 & 70,14 & 61,02 & 74,74 & 79,65 & 42,8 & 37,69 & 58,54 & 69,69 & 22,66 & 72 \\
\hline smušenog & 100,2 & 87,83 & 83,66 & 84,53 & 81,18 & 81,2 & 53,55 & 64,28 & 61,63 & 77,56 & 14,73 & 66 \\
\hline živimo & 157,4 & 85,88 & 69,8 & 65,43 & 105,2 & 100,1 & 103,7 & 78,82 & 93,74 & 95,56 & 27,27 & 64 \\
\hline pernicom & 80,69 & 65,77 & 65,39 & 58,61 & 51,65 & 73,69 & 40,18 & 46,87 & 56 & 59,87 & 12,90 & 54 \\
\hline prirodom & 65,15 & 83,49 & 70,88 & 48,32 & 70,2 & 53,51 & 50,02 & 53,6 & 67,69 & 62,54 & 11,84 & 49 \\
\hline opeke & 65,71 & 53,71 & 52,48 & 33,67 & 41,34 & 38,75 & 37,17 & 62,34 & 40,47 & 47,29 & 11,60 & 50 \\
\hline kritike & 72,93 & 81,07 & 45,19 & 89,19 & 50,41 & 58,67 & 57,58 & 68,61 & 75,47 & 66,57 & 14,61 & 63 \\
\hline sadnice & 114,1 & 103,1 & 86,45 & 150,3 & 68,53 & 95,7 & 106,9 & 79,61 & 124,7 & 103,30 & 24,77 & 98 \\
\hline
\end{tabular}

*Trajanje vokala označava normaliziranu vrijednost prema tempu artikulacije modelske govornice hrvatskog standarda, a ne stvarno izmjereno trajanje vokala; ** Osjenčane su vrijednosti vokala u slogovima s percipiranom zanaglasnom dužinom; ”

Sigurno procijenjene zanaglasne dužine 


\section{Lorna Rajle - Elenmari Pletikos Olof - Blaženka Martinović: Zanaglasne dužine u osječkom govoru}

Tablica 10. Trajanje vokala* osječkih govornika u slogovima s percipiranim prvim zanaglasnim dužinama (uključujući i sigurnu i nesigurnu procjenu) - usporedba s modelskom govornicom hrvatskog standarda kada izgovara zanaglasne dužine

\begin{tabular}{|c|c|c|c|c|c|}
\hline Riječ & $\begin{array}{l}\text { Trajanje } \\
\text { vokala } \\
\text { govornika* } \\
(\bar{x})(\mathrm{ms})\end{array}$ & $\mathrm{Sd}$ & $\begin{array}{l}\text { Trajanje } \\
\text { vokala } \\
\text { referentne } \\
\text { govornice } \\
(\mathrm{ms}) \\
\end{array}$ & $\begin{array}{l}\text { Razlika u trajanju vokala } \\
\text { (govornikov kraći od referen- } \\
\text { tnog) }\end{array}$ & $\begin{array}{l}\text { Razlika u trajanju vokala } \\
\text { (govornikov duži od referen- } \\
\text { tnog) }\end{array}$ \\
\hline sputanost & 111,83 & 20,47 & 148 & 36,17 & - \\
\hline privatnik & 120,83 & 5,19 & 159 & 38,17 & - \\
\hline pukovnik & 145,76 & 16,08 & 174 & 28,24 & - \\
\hline nastavnik & 112,40 & 9,33 & 125 & 12,60 & - \\
\hline pasivan & 111,30 & 10,47 & 146 & 34,7 & - \\
\hline siguran & 97,79 & 0 & 171 & 73,21 & - \\
\hline zadužen & 116,15 & 17,50 & 158 & 41,85 & - \\
\hline razdragan & 128,35 & 13,60 & 147 & 18,65 & - \\
\hline jadranski & 111,65 & 12,52 & 70 & - & 41,65 \\
\hline hrvatski & 124,33 & 6,61 & 141 & 16,67 & - \\
\hline mornarski & 89,01 & 14,05 & 105 & 15,99 & - \\
\hline maknemo & 59,8 & 0 & 135 & 75,2 & - \\
\hline zadužim & 141,17 & 9,59 & 176 & 34,83 & 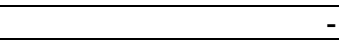 \\
\hline živimo & 94,37 & 17,58 & 118 & 23,63 & - \\
\hline $\begin{array}{l}\text { Razlika (sred- } \\
\text { nja vrijednost) }\end{array}$ & & & & 34,61 & 41,65 \\
\hline $\mathrm{Sd}$ & & & & 19,95 & 0 \\
\hline
\end{tabular}

*Trajanje vokala označava normaliziranu vrijednost prema tempu artikulacije modelske govornice hrvatskog standarda, a ne stvarno izmjereno trajanje vokala

Tablica 11. Trajanje vokala* osječkih govornika u slogovima s percipiranim drugim zanaglasnim dužinama (uključujući i sigurnu i nesigurnu procjenu) - usporedba s modelskom govornicom hrvatskog standarda kada izgovara zanaglasne dužine

\begin{tabular}{|c|c|c|c|c|c|}
\hline Riječ & $\begin{array}{l}\text { Trajanje } \\
\text { vokala } \\
\text { govornika* } \\
(\bar{x})(\mathrm{ms})\end{array}$ & $\mathrm{Sd}$ & $\begin{array}{l}\text { Trajanje vokala } \\
\text { referentne govornice } \\
(\mathrm{ms})\end{array}$ & $\begin{array}{l}\text { Razlika u trajanju } \\
\text { vokala (govornikov } \\
\text { kraći od referent- } \\
\text { nog) }\end{array}$ & $\begin{array}{l}\text { Razlika u trajanju } \\
\text { vokala (govorni- } \\
\text { kov duži od refe- } \\
\text { rentnog) }\end{array}$ \\
\hline mističnost & 72,09 & 3,22 & 111 & 38,91 & - \\
\hline naklonost & 98,30 & 0 & 112 & 13,70 & - \\
\hline pukovnik & 118,60 & 0 & 136 & 17,40 & - \\
\hline komičar & 175,10 & 0 & 149 & - & 26,10 \\
\hline zadrugar & 159,35 & 26,45 & 201 & 41,65 & - \\
\hline nastavnik & 132,40 & 0 & 158 & 25,60 & - \\
\hline razrednik & 126,80 & 0 & 180 & 53,20 & - \\
\hline pasivan & 100,70 & 0 & 147 & 46,30 & - \\
\hline jadranski & 157,80 & 0 & 142 & - & 15,80 \\
\hline zadužim & 111,30 & 0 & 115 & 3,70 & - \\
\hline pomognem & 123,65 & 2,05 & 137 & 13,35 & - \\
\hline spašenog & 126,30 & 0 & 167 & 40,70 & - \\
\hline smušenog & 108,00 & 0 & 168 & 60,00 & - \\
\hline živimo & 177,40 & 0 & 104 & - & 73,40 \\
\hline prirodom & 88,80 & 17,25 & 138 & 49,20 & - \\
\hline kritike & 99,06 & 2,18 & 137 & 37,94 & - \\
\hline sadnice & 153,50 & 11,03 & 215 & 61,50 & - \\
\hline Razlika (srednja vrijednost) & & & & 35,94 & 38,43 \\
\hline $\mathrm{Sd}$ & & & & 18,35 & 30,72 \\
\hline
\end{tabular}

*Trajanje vokala označava normaliziranu vrijednost prema tempu artikulacije modelske govornice hrvatskog standarda, a ne stvarno izmjereno trajanje vokala 


\section{EZZIKOSLOVLIE \\ 21.1 (2020): 53-80}

Tablica 12. Trajanje vokala* u slogovima s percipiranim prvim zanaglasnim dužinama (uključujući i sigurnu i nesigurnu procjenu) - usporedba s modelskom govornicom kada s namjerom ne izgovara zanaglasne dužine

\begin{tabular}{|c|c|c|c|c|c|}
\hline Riječ & $\begin{array}{l}\text { Trajanje } \\
\text { vokala } \\
\text { govorni- } \\
\text { ka* } \\
(\bar{x})(\mathrm{ms}) \\
\end{array}$ & $\mathrm{Sd}$ & $\begin{array}{l}\text { Trajanje vokala } \\
\text { referentne govor- } \\
\text { nice }(\mathrm{ms})\end{array}$ & $\begin{array}{l}\text { Razlika u trajanju } \\
\text { vokala (govornikov } \\
\text { kraći od referent- } \\
\text { nog) }\end{array}$ & $\begin{array}{l}\text { Razlika u trajanju } \\
\text { vokala } \\
\text { duži od referentnog) }\end{array}$ \\
\hline sputanost & 95,99 & 18,40 & 82 & - & 13,99 \\
\hline privatnik & 91,42 & 9,41 & 63 & - & 28,42 \\
\hline pukovnik & 103,18 & 21,40 & 58 & - & 45,18 \\
\hline nastavnik & 95,19 & 17,42 & 45 & - & 50,19 \\
\hline pasivan & 83,71 & 29,40 & 36 & - & 47,71 \\
\hline siguran & 70,44 & 0 & 101 & 30,56 & - \\
\hline zadužen & 81,69 & 17,66 & 79 & - & 2,69 \\
\hline razdragan & 94,29 & 14,60 & 49 & - & 45,29 \\
\hline jadranski & 91,71 & 11,56 & 45 & - & 46,71 \\
\hline hrvatski & 77,43 & 8,11 & 64 & - & 13,43 \\
\hline mornarski & 72,31 & 13,62 & 56 & - & 16,31 \\
\hline maknemo & 61,92 & 0 & 50 & - & 11,92 \\
\hline zadužim & 102,80 & 13,17 & 86 & - & 16,80 \\
\hline živimo & 73,67 & 18,49 & 63 & - & 10,67 \\
\hline Razlika (srednja vrijednost) & & & & 30,6 & 26,87 \\
\hline $\mathrm{Sd}$ & & & & 0 & 17,51 \\
\hline
\end{tabular}

*Trajanje vokala označava normaliziranu vrijednost prema tempu artikulacije modelske govornice hrvatskog standarda, a ne stvarno izmjereno trajanje vokala

Tablica 13. Trajanje vokala* u slogovima s percipiranim drugim zanaglasnim dužinama (uključujući i sigurnu i nesigurnu procjenu) - usporedba s modelskom govornicom kada s namjerom ne izgovara zanaglasne dužine

\begin{tabular}{|c|c|c|c|c|c|}
\hline Riječ & $\begin{array}{l}\text { Trajanje } \\
\text { vokala } \\
\text { govornika* } \\
(\bar{x})(\mathrm{ms})\end{array}$ & $\mathrm{Sd}$ & $\begin{array}{l}\text { Trajanje vokala } \\
\text { referentne govor- } \\
\text { nice }(\mathrm{ms})\end{array}$ & $\begin{array}{l}\text { Razlika u trajanju } \\
\text { vokala (govornikov } \\
\text { kraći od referent- } \\
\text { nog) }\end{array}$ & $\begin{array}{l}\text { Razlika u trajanju } \\
\text { vokala (govornikov } \\
\text { duži od referentnog) }\end{array}$ \\
\hline mističnost & 66,31 & 6,76 & 32 & - & 34,31 \\
\hline naklonost & 81,46 & 0 & 72 & - & 9,46 \\
\hline pukovnik & 88,86 & 0 & 81 & - & 7,86 \\
\hline komičar & 157,90 & 0 & 55 & - & 102,90 \\
\hline zadrugar & 131,60 & 27,5 & 114 & - & 17,60 \\
\hline nastavnik & 106,9 & 0 & 88 & - & 18,90 \\
\hline razrednik & 95,21 & 0 & 65 & - & 30,21 \\
\hline pasivan & 81,30 & 0 & 73 & - & 8,30 \\
\hline jadranski & 136,20 & 0 & 43 & - & 93,20 \\
\hline zadužim & 82,00 & 0 & 51 & - & 31,00 \\
\hline pomognem & 82,93 & 7,25 & 52 & - & 30,93 \\
\hline spašenog & 96,98 & 0 & 72 & - & 24,98 \\
\hline smušenog & 87,73 & 0 & 66 & - & 21,73 \\
\hline živimo & 157,40 & 0 & 64 & - & 93,40 \\
\hline prirodom & 68,50 & 21,20 & 49 & - & 19,50 \\
\hline kritike & 82,33 & 9,70 & 63 & - & 19,33 \\
\hline sadnice & 128,60 & 30,69 & 98 & - & 30,60 \\
\hline Razlika (srednja vrijednost) & & & & 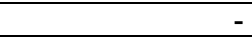 & 34,95 \\
\hline $\begin{array}{lllll} & y\end{array}$ & & & & & 30,53 \\
\hline
\end{tabular}

*Trajanje vokala označava normaliziranu vrijednost prema tempu artikulacije modelske govornice hrvatskog standarda, a ne stvarno izmjereno trajanje vokala 


\section{Adrese autorica:}

Filozofski fakultet Osijek

Lorenza Jägera 9, Osijek

E-mail: lorna.rajle@gmail.com

Filozofski fakultet Sveučilišta u Zagrebu

Ivana Lučića 3, Zagreb

E-mail: epletikos@ffzg.hr

Filozofski fakultet

Sveučilište Jurja Dobrile u Puli

I. Matetića Ronjgova 1, Pula

E-mail: bmartino@unipu.hr

\section{POST-ACCENTUAL LENGTHS IN THE SPEECH OF OSIJEK}

One of the unstable spots of the Croatian orthoepic norm is the accentual system and the pronunciation of post-accentual lengths. Recent research on Croatian speech indicates that long and short post-accentual syllables in Croatian urban dialects are mostly not distinguished, and even in the dialects with the Neoštokavian four-accent system the long postaccentual syllables are being reduced (Pletikos Olof 2013). This phenomenon is frequently attributed to the markedness and the low level of prestige of post-accentual lengths among speakers of Croatian (Škarić \& Lazić 2002). Because the standard norm should determine the stylistically neutral and the unmarked, linguists quietly accept the lapse from the regulations in this segment. In the light of studying Croatian urban dialects, this paper aims to describe the realizations of post-accentual lengths in the speech of Osijek, particularly in genitive and instrumental cases of e-declension nouns, in some suffixes, and in the present tense and definite adjective forms. The results are compared with the lengths produced by a model speaker of Standard Croatian when she is intentionally producing and not producing the length. The lengths in her speech are taken as a reference point for the categories of long and short. Previous research has shown that in Osijek, whose speech belongs to the Neoštokavian four-accent system, the lengths not immediately following rising accents most commonly disappear, and the lengths following rising accents weaken (but they do not disappear), especially those following the long-rising accent (Benić 2007). Still, a systematic description of post-accentual lengths for the mentioned word categories does not exist. This research is based on the speech analysis of people from Osijek who read sentences saturated with words with lengths. The results have shown that there is a tendency to reduce post-accentual lengths in certain forms, but the phenomenon is rather rare after rising accents.

Key words: post-accentual lengths; urban speeches; speech of Osijek; usage; norm. 